\title{
REFORMULASI /STINBÂTHHUKUM ISLAM DARI AL-SUNNAH DALAM PERSPEKTIF YÛSUF AL-QARDHÂWÎ
}

\author{
Ainol Yaqin \\ Jurusan Syariah STAIN Pamekasan \\ J1. Raya Panglegur Km.4, Pamekasan, Jawa Timur, 69371 \\ e-mail: ainulfairus@ymail.com
}

\begin{abstract}
Abstrak: Tulisan ini difokuskan pada pemikiran Yûsuf al-Qardhâwî tentang al-Sunnah dalam istinbâth hukum Islam. Teori asasi pemikiran Yusuf al-Qardhâwî berkenaan dengan metode komprehensif (manhaj syumûlî), metode balance (manhaj mutawâzin) dan metode yang memudahkan (manhaj muyassir) menjadi pisau analisis kajian ini. Pada gilirannya, pengkajian atas peran dan fungsi yang melekat pada Rasulullah SAW. adalah urgen guna menguak substansi al-Sunnah. Menurutnya, terkadang Rasulullah SAW. bersabda dalam kapasitasnya sebagai hakim, sekali waktu muncul dari perannya sebagai kepala negara. Beliau juga terkadang berfatwa dalam posisinya sebagai Rasul, atau sebagai manusia biasa. Sebab itu, memperhatikan konteks di mana dan kapan sabda itu dinyatakan adalah sebuah keniscayaan. Penulis menemukan bahwa Yûsuf al-Qardhâwî memformulasikan delapan prinsip pola istinbâth hukum Islam dari al-Sunnah agar relevan dengan perkembangan tempat dan waktu, dengan tetap berpijak pada spirit al-tasyrî‘ dan maqâshid al-syarî‘ah.
\end{abstract}

\begin{abstract}
Reformulation of Distillation of Islamic Law in the Perspective of Yûsuf al-Qardhâwî.This article is focused on the thought of Yûsuf al-Qardhâwî about al-sunnah in the istinbâth of Islamic law. The principle theory of Yûsuf al-Qardhâwî's thought consist of comprehensive method, balance method and simplifying method becomes the theoretical analysis for this study. In turn, the study on the role of Prophet Muhammad is urgently considered to reveal the substance of al-Sunnah. For al-Qardhâwî, at one time, the Prophet could act in the capacity as a judge but in another time as a leader, and as a messenger of Allah which is applicable for universal use. What's more, his own utterance may also represent his personal expression as a lay person. Hence, looking at the context where and when the decree is stated becomes a necessity. The writer finds that Yûsuf al-Qardhâwî formulates 8 principles of istinbâth pattern of Islamic law from al-Sunnah to make it relevant to the development of the space and time, by holding tight to the spirit of al-tasyrî‘ and maqâshid al-syarî́ah.
\end{abstract}

Kata Kunci: al-Sunnah, reformulasi, spirit al-tasyrî‘, maqâshid al-syarî‘ah, hukum Islam 


\section{Pendahuluan}

Teks bukanlah sebuah narasi yang lahir dalam ruang hampa. Sebaliknya, ia acapkali muncul bersentuhan dengan konteks realitas dan sejumlah variabel yang melingkupi dan menyertainya. Ia selalu berdialektika dengan situasi dan kondisi di mana teks itu diaplikasikan. ${ }^{1}$ Sebab itu, untuk memahami sebuah teks secara baik dan benar, tidak terkecuali teks hadis, dibutuhkan pemahaman utuh seputar konteks yang mengitarinya. Pengabaian terhadap memahami konteks yang menyertai sebuah teks dapat berpotensi pada kesalahpahaman dalam mengungkap makna dan pesan teks itu sendiri. Integrasi teks dan konteks ini amat perlu dikolaborasikan agar makna dan pesan yang termuat di dalamnya bisa terungkap. Dengan demikian, untuk mengetahui pemaknaan teks sesuai dengan konteks dalam term ilmu al-Qur'an dan hadis dikenal seputar pembahasan teori asbâb al-nuzûl (sebab peristiwa yang melatarbekangi turunnya ayat), asbâb al-wurûd (sebab peristiwa yang mendasari datangnya hadis), prinsip al-tadarrujfíal-tasyri‘ (penerapan secara bertahap pemberlakuan syariat), nâsikh mansûkh (teks ayat atau hadis membatalkan kedudukan hukum yang lain), al-ta'ârudh wa al-tarjîh $\underline{h}$ (pertentangan dalil-dalil dan metode penyelesaiannya).

Yûsuf al-Qardhâwî berupaya menggagas formula-formula dasar dan standarisasi yang esensial untuk memahami al-Sunnah dengan pemahaman yang benar dan tepat. Adapun yang menjadi harapannya adalah memaksimalkan daya nalar logis dan kritis dalam memahami al-Sunnah untuk mengkontekstualkan dan mengungkap subtansinya supaya sesuai dengan kondisi kekinian dan sejalan dengan perkembangan ruang dan waktu. Di samping itu, di satu sisi sebagai bentuk penepisan terhadap sebagian orang yang minimalisasi pemahaman terhadap al-Sunnah, dimana mereka hanya berpikir secara tekstual dan harfiyah sehingga melahirkan pemahaman yang berkutat di bagian luar saja. Mereka hanya tertunduk pada zhâhir al-Sunnah dengan mengabaikan maqâshid dan ruhnya. Di sisi yang lain sebagai benteng pertahanan sebagai orang yang terlalu berani menginterpretasi al-Sunnah hingga melenceng dari pemaknaan yang sebenarnya. Mereka menceburkan diri untuk memahami al-Sunnah yang pada dasarnya mereka sendiri kurang memahami seutuhnya. Menurut al-Qardhâwî, mereka memasuki rumah tidak melewati palang pintunya. ${ }^{2}$

\section{Sketsa Biografis Yûsuf al-Qardhâwî}

Yûsuf al-Qardhâwî lahir di sebuah desa kecil di Mesir bernama Shaft Turab di tengah Delta pada 9 September 1926. Talenta dan kebrilianan intelektualnya sudah terlihat sejak

\footnotetext{
${ }^{1}$ Nasr Hâmid Abû Zaid, Mafhâm al-Nash: Dirâsah fì Ulûm al-Qur'ân (Kairo: al-Hai'ah alMishriyah al-'Âmmah li al-Kitâb, 1993) h. 11.

${ }^{2}$ Yûsuf al-Qardhâwî, Kaifa Nata'âmal ma'a al-Sunnah al-Nabawiyyah, cet. 2 (Kairo: Dâr al-Syurâq, 2000), h.23.
} 
usia dini. Ia mulai menghapal al-Qur'an di usia 5 sampai 7 tahun dan menyempurnakan hapalannya dengan baik dan bertajwid sewaktu berumur 10 tahun. Sekalipun di usia relatif muda, dia dipercaya mengajar di sejumlah masjid karena kemahiran di bidang al-Qur'an yang sudah digelutinya. ${ }^{3}$ Ia menyelesaikan sekolah dasar dan menengahnya di sebuah lembaga yang bernama "Thantha". Pada saat kelulusannya di tingkatan sekolah menengah umum, dia meraih ranking kedua untuk tingkat nasional, Mesir. Padahal waktu itu dia pernah mengenyam di dalam bui. Setelah itu, ia melanjutnya studinya di Fakultas Ushuluddin Universitas al-Azhar, Kairo. Ia berhasil memperoleh ijazah Perguruan Tinggi pada tahun 1953. ${ }^{4}$ Kemudian beliau mendapat ijazah setingkat S2 dan mendapatkan rekomendasi untuk mengajar di Fakultas Bahasa dan Sastra pada tahun 1954. Pada tahun 1960 dia memperoleh ijazah setingkat Master di bidang konsentrasi ilmu-ilmu al-Qur'an dan Sunnah di Fakultas Ushuluddin. Pada tahun 1973 ia berhasil memperoleh gelar Doktor dengan peringkat summa cum laude, disertasi yang diangkat berjudul al-Zakat wa Atsaruhâ fi Hilli al-Masyakil al-Ijtimấiyyah (Zakat dan Peranannya dalam Memecahkan MasalahMasalah Sosial). Gelar doktor tidak segera diraih bukanlah tanpa sebab. Karena sikap kritis terhadap rezim yang berkuasa menyebabkan ia terlambat mendapatkannya. Al-Qardhâwî mengangkat kaki dari tanah kelahirannya menuju Qatar pada tahun 1961 karena untuk menjauhkan diri dari kekejaman rezim yang berkuasa di Mesir. Di sana, ia mengaktualisasikan ilmunya dengan mendirikan Fakultas Syariah di Universitas Qatar. Di samping itu, ia juga mendirikan Pusat Kajian Sejarah dan Sunnah Nabi. Ia berdomisili di Qatar dan memilih Doha sebagai tempat tinggalnya. ${ }^{5}$

\section{Al-Sunnah dalam Perspektif Yûsuf al-0ardhâwî}

Al-Sunnah adalah interpretasi praktis terhadap al-Qur'an dan juga aplikasi ideal dalam Islam. Nabi dalam konteks ini berperan sebagai penafsir al-Qur'an dan prototipe dalam Islam. Hal ini disarikan dari pengertian terhadap sebuah riwayat dari 'Aisyah sewaktu ia ditanya perihal akhlak Nabi. Jawabnya, "Akhlak Nabi adalah al-Qur'an". ${ }^{6}$ Sebab itu, al-Qardhâwî menyatakan metode praktis untuk mengetahui karakteristik dan pondasi Islam adalah pengetahuan secara terperinci dan komprehensif terhadap al-Sunnah, baik Sunnah qauliyah, filiyah dan taqrîriyah. ${ }^{7}$

${ }^{3}$ Sulaimân Ibn Shâlih, al-Qardhâwî fĩ al-Mîzan (Riyâdh: Dâr al-Jawâb, t.t.), h. 8. h. 443.

${ }^{4}$ Muhammad al-Majdzâb, 'Ulamâ' wa Mufakkirân 'Araftuhum (Beirut: Dâr al-Nafâ'is, 1977),

5Ibn Shâlih, al-Qardhâwî fí al-Mîzan, h. 10.

${ }^{6}$ Ah̆mad Ibn Muhammad Ibn ㅂanbal, al-Musnad, Juz XVII (Kairo: Dâr al-Hadis, 1995), h. 564; Aḥmad Ibn 'Umar Ibn Ibrâhîm al-Qurthubî, al-Muflim limâ Asykala min Talkhîsh Kitâb Muslim, Juz II (Beirut: Dâr Ibn Katsîr, 1996), 378; 'Iyâdh Ibn Mûsâ Ibn 'Iyâdh al-Yahhshabî, Ikmâl al-Mu'im bi Fawâ ' id Muslim, Juz III (t.t.p.: Dâr al-Wafâ', 1998), h. 95; Shafiurrahmmân al-Mubârakfûrî, Minnatu al-Mun'im fí Syarhi Shaĥîh Muslim, Juz I (Riyâdh: Dâr al-Salâm, 1999), 469; Muhyiddîn Ibn Syarf al-Nawawî, Shaĥh Muslim bi Syarh al-Nawawî, Juz VI (Kairo: al-Mathba'ah al-Mishriyah, t.t), 26.

7Al-Qardhâwî, Kaifa Nata'âmal ma'a al-Sunnah al-Nabawiyah, h. 27. 
Dilihat dari segi tingkatan dalil, al-Sunnah adalah sumber kedua di bidang pensyariatan hukum Islam dan taujihat (dahwah/arahan)nya. Para ahli fikih merujuk kepadanya untuk mengistinbâthkan hukum Islam, sebagaimana para juru dakwah dan pakar pendidikan mengkajinya untuk mengungkap makna-makna, nilai-nilai yang mencerahkan dan mutiara hikmah yang menyentuh dan memberi bekas dalam hati. ${ }^{8}$ Terkait dengan bidang pensyariatan hukum Islam, bahasan al-Sunnah selalu dituangkan oleh ulama dalam sejumlah literatur usul fikih dari berbagai aliran mazhab. Tidak berlebihan apa yang diungkapkan oleh alAuzâ'î bahwa al-Qur'an sangat membutuhkan al-Sunnah, dibandingkan al-Sunnah pada al-Qur'an. Sebab al-Sunnah berfungsi sebagai penjelasan al-Qur'an; pemerinci ayat yang bersifat mujmal, pen-taqyîd (pemberi batasan) ayat yang masih mutlak dan pentakhshîsh (pengkhususan) ayat yang berbentuk 'am. Al-Sunnah memperjelas makna yang dimaksudkan dalam al-Qur'an. ${ }^{9}$

Semua ahli fikih dari berbagai haluan mazhab yang tersebar di beberapa daerah, baik mazhab yang masih eksis maupun yang telah sirna, mereka merujuk pada al-Sunnah dalam merumuskan hukum Islam. Sekalipun porsi pengistinbâthannya terdapat sedikit perbedaan. Imam Mâlik mengatakan tidak seorang pun dari ahli fatwa mengesampingkan al-Sunnah dalam mencetuskan fatwanya. Mereka mesti menjadikan al-Sunnah sebagai salah satu dasar dalam berfatwa. ${ }^{10}$ Demikian halnya, Abû Hanîfah melandaskan dasar ijtihadnya pada al-Qur'an, bila tidak ditemukan di dalam al-Qur'an ia merujuk kepada al-Sunnah. Bila di dalam al-Sunnah tidak didapati, ia melacak qaul sahabat. Setelah melakukan penelitian pada dalil-dalil tersebut tidak ditemukan, barulah ia berijtihad. ${ }^{11}$ Sementara itu, Imam al-Syâfiî mengutarakan "jika kamu menemukan di dalam kitabku bertentangan dengan Sunnah Rasulullah, maka berpeganglah pada Sunnahnya dan tinggalkanlah pendapatku." 12

8Ibid., h. 47.

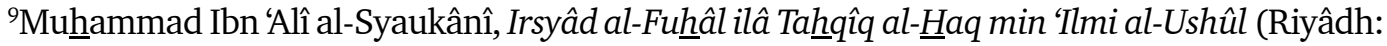
Dâr al-Fadhîlah, 2000), Juz I, h. 189; Muhammad Ibn Bahâdir Ibn 'Abdullâh, al-Bahr al-Muhîth fi Ushûl al-Fiqh, cet. 2, Juz IV (Kuwait: Dâr al-Shafwah, 1992), h. 167; 'Alî Ibn Muhammad al-Âmidî, Muntahâ al-Sâl fí 'Ilmi al-Ushûl (Beirut: Dâr al-Kutub al-'Ilmiyah, 2003), h. 293.

${ }^{10}$ Jalâluddîn Ibn 'Abdurraḥmân Ibn Abî Bakar al-Suyûthî, Miftâh al-Jannah fí al-I'tishâm bi al-Sunnah (Riyâdh: Maktabah al-Sâ'î, 1987) h. 80.

${ }^{11}$ Al-Suyûthî, Miftâh al-Jannah, h. 80; 'Abd al-Wahhâb Khallâf, 'Ilmu Ushûl al-Fiqh, cet. 12 (t.t.p.: Dâr al-Ilmi, 1978) h. 95; Wahbah al-Zuhailî, Ushûl al-Fiqh al-Islâmî, cet. 17, Juz II (Beirut: Dâr al-Fikr, 2009), h. 153.

${ }^{12}$ Ahmad bin Salamah al-Qalyûbî, $\underline{H}$ âsyiyah Qalyûbî, Juz IV (Kairo: Musthafâ al-Bâbî al-

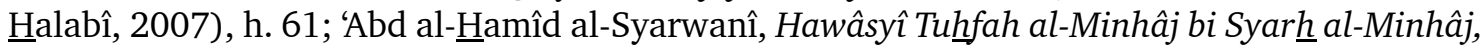
Juz I (Kairo: al-Maktabah al-Tijâriyah al-Kubra, 2007), h. 54; Muhammad bin al-Khathîb al-Syarbînî, Mughnî al-Muhtâjj ilâ Ma'rifati Alfâdl al-Minhâjj, Juz I (Beirut: Dâr al-Ma'rifah, 1998), h. 38; Sulaimân bin Muhammad al-Bujairamî, Bujairamî 'alâ al-Khathîb, Juz I (Beirut: Dâr al-Kutub al'Ilmiyah, 1996), h. 77; Muhammad bin Abî 'Abbâs al-Ramlî, Nihâyah al-Muhtâjj Ilâ Syarh alMinhâj, Juz I (Beirut: Dâr al-Fikr, t.t.), h. 20, Dengan pernyataan berbeda, tapi substansi yang sama, ia menyatakan jika kamu menemukan dalam kitabku menyalahi sunnah Rasulullah, berpeganglah pada sunnah Rasulullah dan tinggalkanlah pendapatku. Abû Zakariyâ' Muhy al-Dîn 
Al-Qardhâwî menandaskan terdapat tiga metode al-Sunnah dalam menjawab segala problem kehidupan manusia. Pertama, metode komprehensif (manhaj syumûlî). Maksudnya al-Sunnah telah menjabarkan segala aspek dan ruang lingkup kehidupan manusia. Mulai lahir sampai meninggal, dan bahkan sejak dalam kandungan hingga hal ihwal setelah kematian. Di samping itu, al-Sunnah juga membahas aturan dan etika dalam beraktivitas keseharian; di rumah, pasar, masjid, jalan, dan tempat bekerja. Ia pula mengatur tatacara hubungan yang baik dengan Allah SWT., jiwa, keluarga, sesama umat seagama, umat beragama dan bahkan mengatur hubungan manusia dengan hewan dan benda-benda tidak bernyawa. ${ }^{13}$

Kedua, metode balance (manhaj mutawâzin). Dalam pengertian, al-Sunnah juga mengajarkan umat manusia untuk menjalani hidup secara seimbang di berbagai dimensi kehidupan; memberlakukan seimbang pada ruh dan jasad, akal dan hati, dunia dan akhirat, idealitas dan realitas, pikir dan amal, alam gaib dan alam nyata, kebebasan dan tanggungjawab, individual dan sosial. Ia adalah metode moderat bagi umat Muhammad SAW. Spirit yang terkandung dalam al-Sunnah adalah nilai-nilai kemoderatan. ${ }^{14}$ Sebab itu, Ketika Rasulullah melihat 'Abd Allâh Ibn 'Umar berlebih-lebihan dalam melaksanakan puasa, ibadah di waktu malam dan membaca al-Qur'an, ia pun menegurnya untuk beribadah dalam batas kewajaran. Karena badan, mata, keluarga dan pasangan memiliki hak yang harus dipenuhi. ${ }^{15}$ Rasulullah mengajarkan umat manusia guna melaksanakan kewajiban dan memenuhi hak secara tepat dan proporsional. Oleh karenanya, segala bentuk sikap

bin Syarah al-Nawawî, al-Majmâ' Syarah al-Muhaddzab, Jilid I (Beirut: Dâr al-Fikr, t.t.), h. 104; Muhammad bin Muhammad al-Ghazâlî, al-Wasîth fí al-Madzhab, Jilid I (Kairo: Dâr al-Salâm, 1997), h. 88; al-Suyûthî, Miftâh al-Jannah, h. 81.

${ }^{13}$ Di dalam kitab-kitab sunan (jama' al-Sunnah) atau Hadis diterangkan berbagai penjelasan yang berkaitan dengan syariah, akidah, akhlak, adab (etika), dan fadhâ 'il (keutamaan-keutamaan). Tidak satu pun persoalan kehidupan umat manusia terlewati dari bidikan al-Sunnah, baik dinyatakan secara terperinci maupun bersifat ketentuan umum. Hal itu dapat ditemukan dalam kitab-kitab sunnah atau Hadis yang disusun, dikelompokkan sesuai dengan babnya oleh ahli Hadis, di antaranya Shahîh al-Bukhârî dan Shahîh $\underline{h}$ Muslim, Sunan Abî Dâud, Sunan al-Turmudzî, Sunan al-Nasầî, Sunan al-Baihââî, Sunan al-Dârimî, Sunan al-Dâruquthnî.

${ }^{14}$ Yûsuf al-Qardhâwî, al-Islâm Hadhârah al-Ghad (Kairo: Mahtabah Wahbah, 1995), h. 152;

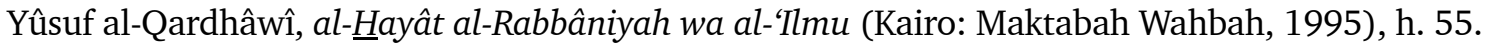

${ }^{15}$ Jalâl al-Dîn 'Abdurrahmân al-Suyûthî, al-Tausyîkh Syarh al-Jâmi' al-Shahîhh, Juz IV (Riyâdh:

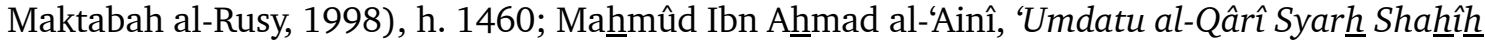
al-Bukhârî, Juz XI (Beirut: Dâr al-Kutub al-'Ilmiyah, 2001), h. 126; Ahmad Ibn 'Alî Ibn Hajar al-

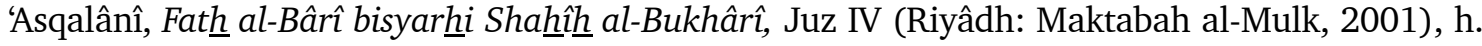
256; 'Alî Ibn Khalaf Ibn 'Abd al-Mulk, Syarh Shahي̣̂h al-Bukhârî libni Batthâl, Juz IV (Riyadh: Maktabah al-Rusy, t.t.), h. 119; al-Nawawî, Shaḥ̂̂ Muslim bi Syarh al-Nawawî, Juz VIII, h. 42; Shafiurrahmân al-Mubârakfûrî, Minnatu al-Mun'im fí Syarh Shahîh Muslim, Juz II (Riyâdh: Dâr al-Salâm, 1999), 196; al-Yahshabî, Ikmâl al-Mu lim bi Fawâ 'idi Muslim, Juz IV, h. 123; al-Qurthubî, al-Muflim limâ Asykala min Talkhîsh Kitâb Muslim, Juz III, h. 225; Mahmûd Muhammad Khatthâb al-Subkî, alManhal al-ÁAzbu al-Maurâd, Juz X (Beirut: Mua'ssasah al-Târîkh al-'Arabi, t.t.), h. 180; al-Husain Ibn Mas'âd al-Baghawî, Syarh al-Sunnah, Juz VI (Beirut: al-Maktab al-Islamî, 1983), h. 336. 
dan tindakan ekstrim dalam melakukan suatu perbuatan bukan merupakan ajaran Islam, dan bahkan dianjurkan untuk ditinggalkan.

Ketiga, metode yang memudahkan (manhaj muyassir). Di antara karakteristik alSunnah adalah mengandung kemudahan dan tidak sukar untuk diamalkan. Ajaran Sunnah Nabi tidak memberatkan umat manusia dalam urusan agama dan dunianya. Semua ajaran al-Sunnah berada dalam taraf dimampui umat manusia. ${ }^{16} \mathrm{Hal}$ ini, merupakan salah satu representasi Rasulullah diutus oleh Allah SWT. sebagai rahmat bagi semesta alam. Dalam suatu riwayat dinyatakan bahwa Nabi berpesan pada umatnya untuk mempermudah, jangan mempersulit diri dan orang lain, menginformasikan kabar gembira dan jangan menyebarkan kabar yang menyebabkan orang lain menjadi enggan. ${ }^{17}$

Bertolak dari ketiga prinsip dasar yang telah digagas oleh Yûsuf al-Qardhâwî, maka ia menggariskan tiga hal yang mesti dijauhi dalam membahas dan mengkaji al-Sunnah. Pertama, penyimpangan kelompok ekstrim (tahrîf alhi al-ghuluw). Penyimpangan atau distorsi muncul dari sikap ekstrim yang menjauhi dari nilai-nilai moderat, toleransi dan kemudahan yang menjadi karakteristik syariat Islam. Sebab itu, Nabi SAW. sangat tegas melarang bersikap ekstrim dalam persoalan agama karena dapat meruntuhkan dan merusak nilai-nilai mulia dalam keberagamaan itu sendiri. ${ }^{18}$ Kedua, pengakuan orangorang sesat (intihâl ahli al-bâthil), yaitu memasukkan berbagai macam bidah yang jelas berlawanan dengan akidah, syariah, ushûl dan furû' ke dalam bagian al-Sunnah. Menurut Yûsuf al-Qardhâwî agar terhindar dari kekeliruan ini, ia menyarankan adanya ketelitian dalam masalah isnâd. Meneliti secara seksama mengenai kesahihan hadis melalui pengujian validitas hadis dari segi perawi, sanad dan matan yang meliputi sisi tsiqah, adil, dhâbith, tidak cacat zhâhir maupun samar, terbebas dari setiap bentuk syâdz dan 'illat. ${ }^{19}$ Ketiga,

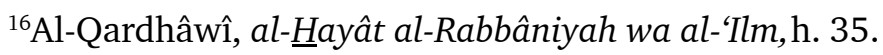

${ }^{17}$ Aḥmad Ibn Muhammad al-Khathîb al-Qasthalânî, Irsyâd al-Sâri ilâ Syarhi Shahîh alBukhârî, Juz I (t.t.p.: al-Mathba'ah al-Kubrâ al-Amîriah, 1323 H), h. 169; al-'Asqalânî, Fath al-

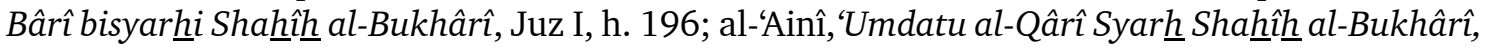

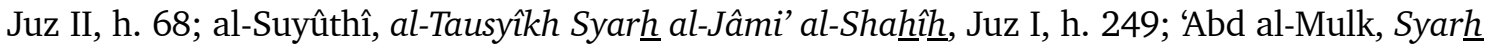

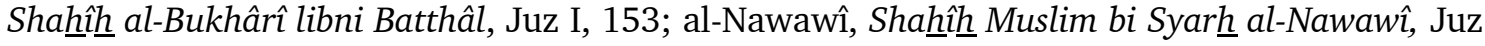
XII, h. 41; Mûsâ Syâhin Lâsyin, Fath al-Mu’im Syarh Shahîh Muslim, Juz VII (Beirut: Dâr al-Syurûq, 2002), h. 87; al-Mubârakfûrî, Minnatu al-Mun'im fí Syarhi Shahîh $\underline{h}$ Muslim, Juz III, h. 170; alYahshabî, Ikmâl al-Mu’lim bi Fawâ 'idi Muslim, Juz VI, h. 37; al-Qurthubî, al-Muflim limâ Asykala min Talkhîsh Kitâb Muslim, Juz III, h. 517.

${ }^{18}$ Jalâluddin al-Suyûthî, Sunan al-Nasấî, Jilid III (Kairo: Syirkah al-Qudsi, 2011), h. 243; Ahmad Ibn Muhammad Ibn Hanbal, al-Musnad, Jilid II (Kairo: Dâr al-Hadis, 1995), h. 427.

${ }^{19}$ Yûsuf al-Qardhâwî, Kaifa Nata'âmal ma'a al-Sunnah al-Nabawiyyah, h. 39. Lihat juga, Manshâr Ibn Muhammad Ibn 'Abd al-Jabbâr al-Sam'ânî, Qawâthi'u al-Adillah fí al-Ushûl, Juz I (Beirut: Dâr al-Kutub al-'Ilmiyah, 1997), h. 343; al-Husain Ibn Rasyîq al-Mâlikî, Lubâb al-Mahshâl fí 'Ilmi al-Ushûl, Jilid I (t.t.p.: Dâr al-Buhâst li Dirâsât al-Islâmiah wa Ihyầ' al-Turâts, 2001), h. 355; 'Abd al-'Azîz Ibn Aḥmad al-Bukhârî, Kasyfu al-Asrâr 'an Ushûl Fakhri al-Islâm al-Bazdawî,, Juz II (Beirut: Dâr al-Kutub al-'Ilmiyah, 1997), h. 571; 'Alî Ibn Sulaimân al-Mardawî al-Hanbalî, al-Tahbîr Syarh al-Tahrîr fĩ Ushûl Fiqh, Jilid IV (Riyâdh: Maktabah al-Rusy, t.t.), h. 1852; 'Ubaidillâh Ibn 'Umar Ibn 'Isa al-Dabûsî, Taqwil al-Adillah fỉ Ushûl al-Fiqh (Beirut: Dâr al-Kutub al-Ilmiyah, 2001), 
penafsiran orang-orang bodoh (ta'wîl ahli al-jahl). Penakwilan yang keliru dan pemahaman yang buruk datang dari orang-orang yang tidak mengerti pada substansi, hakikat dan hikmah syariat Islam. Mereka terjerumus pada pemahaman yang menyimpang dengan berpaling pada ayat-ayat muhkkamat dan mendaku pada ayat-ayat mutasyâbihat dengan melakukan penakwilan yang dibangun atas hawa nafsu. ${ }^{20}$ Dengan demikian, pemahaman yang benar terhadap al-Sunnah adalah berpedoman pada sikap moderat, yaitu tidak berlebihan atau ektrim, tidak terseret dalam kelompok yang sesat dan tidak tenggelam dalam golongan yang bodoh.

Lebih lanjut, al-Qardhâwî menguraikan langkah-langkah yang seharusnya dipedomani oleh umat Islam ketika melakukan pengkajian dan pemahaman terhadap al-Sunnah. Menurutnya, sekurang-kurangnya ada tiga prinsip dasar dalam berinteraksi terhadap alSunnah. Pertama, memastikan otentisitas dan validitas al-Sunnah sesuai dengan barometer yang telah digariskan oleh para ahli yang kompeten di bidangnya. Dalam hal ini, perlu melakukan pengkajian terhadap al-Sunnah dari aspek sanad ataupun matan, baik Sunnah qauliyah, filiyah dan taqrîriyah. Oleh karenanya, pengkaji dan pemerhati al-Sunnah harus merujuk pada keterangan terkait dengan hadis dari segi shahîh, dha'îf, maqbûl dan mardûd yang telah dirumuskan oleh ahli hadis. ${ }^{21}$ Kedua, memahami teks hadis secara baik dan

h. 185; Sulaimân Ibn 'Abd al-Qawî Ibn 'Abd al-Karîm Ibn Saî̀d al-Thâfí, Syarhu Mukhtashar al-Raudhah, Juz II (Beirut: Mu`assasah al-Risalah, 1987), h. 136; Mahnmûd Ibn 'Abd Raḩmân Ibn Aḥmad alAshfahânî, Bayân al-Mukhtashar Syarhhu Mukhtashar Ibn $\underline{H} a ̂ j i b$, Juz I (Jeddah: Dâr al-Madani, 1986), h. 687; Muhammad Ibn Muhammad Ibn 'Abd al-Rahmân, Taisîr al-Wushûl ilâ Minhâj al-Ushûl min al-Manqâl wa al-Ma'qâl, Juz IV (Kairo: al-Fârâq al-Hadisah, 2002), h. 314; Muhammad al-Amîn Ibn Muhammad al-Mukhtâr al-Syinqithî, Mudzakkirah fí Ushûl al-Fiqh (Madinah: Maktabah al-'Ulûm wa al-Hikam, t.t), h. 135; Muhammad Ibn 'Umar Ibn Husain al-Râzî, al-Mahhshâl fí 'Ilm al-Ushûl, Juz IV (Beirut: Mu'assasah al-Risâlah, t.t.), h. 393; Muhammad Ibn ㅂusain Ibn Hasan al-Jaizanî, Ma'âlimu Ushûl al-Fiqh 'inda Ahli al-Sunnah wa al-Jamâ'ah (Riyâdh: Dâr Ibn al-Jauzî, 1996), h. 153; Muhammad Ibn Yûsuf al-Jazarî, Mírâj al-Minhâj, Juz II (Kairo: Mathba'ah al- $\underline{\text { Husain }}$ al-Islâmiah, 1993), h. 47; Zainuddîn Ibn Ibrâhîm Ibn Nujaim, Misykât al-Anwâr fì Ushûl al-Manâr, Juz II (Kairo: Mushthafâ al-Bâbî al-Halabî, 1936), h. 93; 'Umar Ibn Muhammad Ibn 'Umar alKhabbâzî, al-Mughnî fì Ushûl al-Fiqh (Jeddah: Dâr al-Madani, 1403 H) h. 199.

${ }^{20}$ Yûsuf al-Qardhâwî, Kaifa Nata'âmal ma'a al-Sunnah al-Nabawiyyah, h. 41.

${ }^{21}$ Hadis dilihat dari aspek kuat dan lemahnya terbagi pada tiga macam, yaitu: Hadis maqbul (Hadis yang dapat diterima), Hadis mardud (Hadis yang ditolak) dan Hadis musytarak (Hadis yang dapat diterima dan ditolak). Hadis maqbul terdiri dari Hadis sahih dan hasan, sedangkan Hadis mardud meliputi Hadis dha'if, mu'allaq, mu'addlal, munqati', mudallas, mu'an'an, maudhu', matruk, munkar, ma'ruf, mu'allal, mudarraj, maqlub. Sementara Hadis yang dapat diterima dan ditolak mencakup Hadis marfu', mauquf, maqthu', musnad dan muttashil. Hadis sahih adalah Hadis yang muttashil (bersambung) sanadnya, diriwayatkan oleh orang 'adil dan dhâbith (kuat daya ingatan) sempurna dari perawi yang setingkat, selamat dari kejanggalan (syadz), dan cacat ('illat). Sedang Hadis hasan adalah Hadis yang bersambung sanadnya, diriwayatkan oleh orang adil, kurang sedikit ke-dhâbit-annya, tidak ada kesangsian (syadz) dan tidak ada 'illat. Kriteria Hadis hasan sama dengan kriteria Hadis sahih. Perbedaannya hanya terletak pada sisi ke-dhâbithannya yaitu Hadis sahih lebih sempurna ke-dhâbith-annya dibandingkan dengan Hadis hasan. Tetapi jika dibandingkan dengan ke-dhâbith-an perawi Hadis dhâ'if tentu belum setara, ke-dhâbithan perawi Hadis hasan lebih dominan. Sementara Hadis dhấif ialah Hadis yang tidak memenuhi 
tepat. Hal ini dapat diupayakan dengan pendekatan kaidah-kaidah bahasa Arab, mengetahui konteks hadis, asbâb al-wurûd, kesesuaian dengan al-Qur'an dan Sunnah-Sunnah Nabi lainnya, sejalan dengan prinsip-prinsip umum dan maqâshid kulliyah serta membedakan tablîgh al-risâlah dan ghair tablîgh al-risâlah. Ketiga, memastikan teks hadis tidak bertentangan dengan dalil yang lebih kuat, semisal al-Qur'an atau hadis-hadis lain yang lebih unggul dari segi perawi, kesahihan, kesesuaian dengan asal, hikmah al-tasyri' dan maqâshid al'ammah. ${ }^{22}$

\section{Metode-Metode Istinbâth Hukum Islam dari al-Sunnah}

Dengan tujuan bisa memahami al-Sunnah dengan baik dan benar, Yûsuf al-Qardhâwî menformulasikan delapan metode dalam menginterpretasi dan menyarikan makna dari al-Sunnah:

\section{Memahami al-Sunnah sesuai dengan Petunjuk al-Qur'an}

Untuk memahami al-Sunnah secara benar, jauh dari penyimpangan, pemalsuan dan tidak terjerumus pada penakwilan yang keliru, mesti dipahami sesuai dengan petunjuk al-Qur'an. Hal ini dibangun atas ketetapan bahwa al-Qur'an adalah sumber utama dan pertama yang menempati urutan teratas dalam hierarki urutan dalil-dalil hukum Islam. Di samping itu, al-Qur'an merupakan spirit eksistensi Islam dan asas bangunannya. Ia adalah sumber utama rujukan bagi semua perundang-undangan dalam Islam. ${ }^{23}$ Sedangkan al-Sunnah berfungsi sebagai penjelas, perinci aturan-aturan hukum yang ditegaskan dalam al-Qur'an, baik dalam hal-hal yang bersifat teoritis ataupun implementasi praktis terhadap al-Qur'an. ${ }^{24}$ Oleh karenanya, al-Sunnah yang sahih tidak mungkin ber-

kriteria Hadis sahih, dan tidak pula menghimpun standarisasi Hadis hasan. Mahmûd al-Thahân,

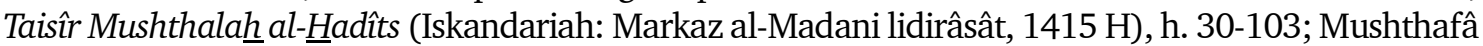

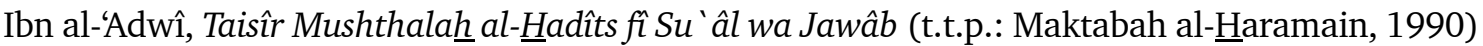

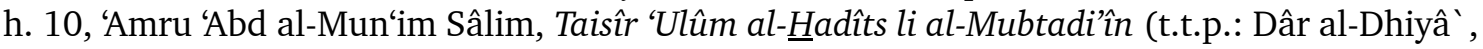
2000) h. 14.

${ }^{22}$ Yûsuf al-Qardhâwî, Kaifa Nata'âmal ma'a al-Sunnah al-Nabawiyyah, h.47.

${ }^{23} Y$ ûsuf al-Qardhâwî, Kaifa Nata'âmal ma'a al-Sunnah al-Nabawiyah, h. 115. Lihat juga, Wahbâh al-Zuhailî, Ushûl al-Fiqh al-Islâmî, Juz I (Beirut: Dâr al-Fikr, 2009), h. 427; Muhammad al-Khudharî Bek, Ushûl al-Fiqh (Mesir: al-Maktabah al-Tijâriyah al-Kubrâ, 1969), h. 210.

${ }^{24}$ Fungsi al-Sunnah terhadap al-Qur'an ada tiga aspek, yaitu: pertama, as-sunnah berfungsi sebagai penegasan terhadap hukum-hukum yang telah diterangkan al-Qur'an. Kedua, as-sunnah berfungsi menjelaskan makna yang dimaksud dalam al-Qur'an. Ketiga, as-sunnah berperan menetapkan hukum yang tidak diterangkan dalam al-Qur'an. Muhammad Ibn Idrîs al-Syâfiî̀, al-Risâlah (Beirut: Dâr al-Kutub al-'Ilmiah, t.t) h. 91-92; Jalâluddîn Ibn 'Abd Rahmân Ibn Abû Bakar al-Suyûthî, Miftâh al-Jannah fí al-I'tishâm bi al-Sunnah (Riyâdh: Maktabah al-Sâ'î, 1987), h. 34; Muhammad ibn Husain ibn Hasan al-Jauzânî, Ma'âlim Ushûl al-Fiqh 'inda Ahli al-Sunnah wa al-Jama'ah, h. 123; Ibn Qayyim al-Jauziyah, I'lâm al-Muwaqqi î̀n 'an Rabbil 'Âlamîn, Jilid I (Riyâdh: Dâr Ibn al-Jauzî, 1423H), h. 166; Muhammad ibn Bahâdir ibn 'Abdullah, al-Bahru al-Muhîth fí Ushûl al-Fiqh, Juz 
tentangan dengan ayat-ayat al-Qur'an yang muhkamat dan keterangan-keterangannya yang jelas. Dengan demikian, jika ternyata didapati pertentangan antara al-Sunnah dengan al-Qur'an, maka besar kemungkinan disebabkan tiga hal, yaitu al-Sunnah tersebut secara kualitas tergolong al-Sunnah yang tidak sahih, boleh jadi juga pertentangan itu dikarenakan pemahaman yang keliru atau bisa saja pertentangan itu bersifat semu semata dan bukan substansi. ${ }^{25}$

Contoh metode pertama ini adalah hadis:

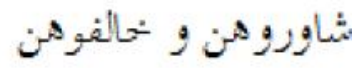

Bermusyawarahlah bersama mereka, tetapi janganlah menyetujui (hasil musyawarahnya). ${ }^{26}$

Menurut penilaian Yûsuf al-Qardhâwî hadis ini adalah hadis palsu dan tidak dapat diterima karena bertentangan dengan firman Allah tentang sikap kedua orangtua terhadap anaknya yang masih dalam masa penyusuan, yaitu sebagai berikut:

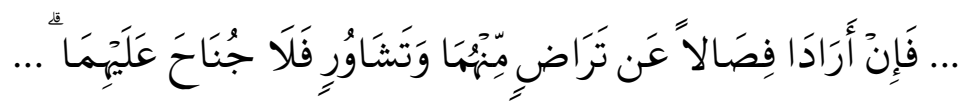

Apabila keduanya ingin menyapih (sebelum dua tahun) dengan kerelaan keduanya dan permusyawaratan, Maka tidak ada dosa atas keduanya (Q.S. al-Baqarah/2: 233).

IV, h. 165; Muhammad al-Khudharî Bek, Ushûl al-Fiqh, 208; Wahbâh al-Zuhailî, al-Wajîz fì Ushûl al-Fiqh (Beirut: Dâr al-Fikr, 1999) h. 38-39; Ibn Qayyim mengemukakan bahwa merujuk dan mengamalkan al-sunnah adalah suatu kewajiban semisal al-Qur'an, sekalipun ia berada di tingkatan kedua. Hal ini, diterangkan secara jelas di dalam al-sunnah shahîhah. Sebab, tidak seorang pun bisa menemukan solusi terhadap problem hukum yang dihadapi bilamana berpaling dari alsunnah. Al-Jauziyah, I'lâm al-Muwaqqi'în 'an Rabbil 'Âlamîn, Jilid I, h. 167.

${ }^{25}$ Yûsuf al-Qardhâwî, Kaifa Nata'âmal ma'a al-Sunnah al-Nabawiyah, h. 115. Menurut imam al-Syâthibî, perbenturan dalil-dalil syara' hanya terbatas pada kulit saja. Menurutnya, pertentangan itu bisa terjadi dalam dalil yang qath $\hat{\imath}$ dan bisa juga dalil zhannî, selama kedua dalil itu satu derajat. Bila pertentangan itu terjadi antara dalil yang tidak sederajat, maka dalil yang lebih kuat diamalkan. Seperti al-Qur'ân bertentangan dengan Hadis ahâad, maka dalil yang dijadikan pedoman adalah al-Qur'ân, karena dari segi periwayatannya al-Qur'ân bersifat qhath '̂̀, sedangkan Hadis ahâad bersifat zhannî. Abû Ishâq Ibrâhîm al-Lakhmî al-Syâthibî, al-Muwâfaqat fî Ushûl alAhkâm, Jilid II (Beirut: Dâr al-Fikr, t.t.), h. 63. Lihat juga, al-Syaukânî, Irsyâd al-Fuhâhl ilâ Tahquîq al-

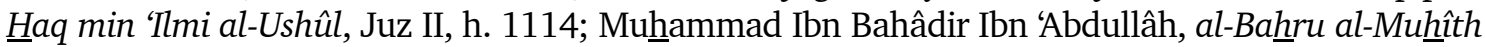
fí Ushûl al-Fiqh, Juz VI, 111; Seirama dengan pandangan ini, Wahbah al-Zuhailî berpendapat pertentangan antara kedua dalil itu hanya dalam penilaian mujtahid sesuai dengan ketajaman analisa dan kekuatan nalar pikirnya, bukan pertentangan yang bersifat subtansial, karena imposimble syara' mengundangkan dua dalil yang berpunggungan pada satu kasus dan satu waktu. Wahbah al-Zuhailî, Ushûl al-Fiqh al-Islâmî, Jilid II, h. 1175. Lihat juga, Muhammadi Ibn Hasan al-Badakhsyî, Manâhij al-'Uqûl, Juz III (Mesir: Mathba'ah Muhammad 'Alî Shâbih, t.t.), h. 151; Muhammad Ibn Nizhâmuddîn Muhammad al-Sahalawî al-Anshârî, Fawâtih al-Rahamât,, Juz II (Beirut: Dâr al-Kutub al-'Ilmiah, 2002), h. 235; Ahmad Ibn Idrîs Ibn 'Abdurrahmân al-Shanhâjî al-Qarâfí, Nafâ ' is al-Ushûl fí Syarh al-Mahshâl, Juz VIII (Riyâdh: Nazzâr Mushthafâ al-Bâz, 1995), h. 3648; 'Abdullâh Ibn 'Umar al-Baidhâwî, Nihâyah al-Sâl fí Syarhi Minhâj al-Ushûl, Juz IV (Beirut: Dâr al-Fikr, 1993), h. 433.

${ }^{26}$ Yûsuf al-Qardhâwî, Kaifa Nata'âmal ma'a al-Sunnah al-Nabawiyyah, h. 114. 
Kandungan hadis tersebut bertolak belakang dengan penjelasan al-Qur'an. Dalam konteks ini, harus dipahami dengan cara melihat makna hadis yang diperkuat oleh al-Qur'an, karena isi hadis (cabang) sebagai penjelas al-Qur'an tidak akan mengandung makna yang berparadoks dengan al-Qur'an (pokok) sebagai sesuatu yang dijelaskan.

\section{Mengumpulkan Hadis-Hadis yang Satu Tema Bahasan}

Untuk memahami Sunnah dengan baik dan benar, dapat dilakukan dengan cara mengumpulkan hadis-hadis sahih yang bertema sama. Setelah pengelompokan hadis-hadis setema, langkah berikutnya adalah mengembalikan kandungannya yang mutasyâbih kepada yang muhkam, membatasi yang mutlak dengan yang muqayyad dan menafsirkan yang 'am dengan yang khas. Dengan hal itu, makna yang dimaksud menjadi jelas dan satu sama lain tidak terjadi pertentangan. ${ }^{27}$

Metode ini dilandaskan pada fungsi-fungsi Sunnah terhadap al-Qur'an. Al-Sunnah berfungsi menafsirkan dan menjelaskan makna-maknanya dengan memperinci ayat-ayat yang global, menafsirkan yang masih samar, men-takhsis yang umum dan membatasi yang mutlak. Dengan demikian, ketentuan-ketentuan ini sangat penting diterapkan dalam mengkaji Sunnah. Mencukupkan diri dengan pengertian lahiriah suatu hadis saja tanpa memperhatikan hadis-hadis lainnya, dan nash-nash lain yang berkaitan dengan topik tertentu seringkali menjerumuskan orang ke dalam kesalahan, dan menjauhkannya dari kebenaran mengenai maksud sebenarnya dari konteks hadis tersebut.

Salah satu contoh yang berkenaan dengan metode ini adalah hadis-hadis yang menerangkan larangan "memakai sarung sampai di bawah mata kaki", dan ancaman keras terhadap pelakunya. Hadis-hadis tersebut dibuat sandaran oleh sejumlah orang untuk melontarkan kritik yang tajam pada siapa pun yang tidak menurunkan pakaiannya sampai di atas mata kaki. Mereka bahkan bersikap ekstrim, sehingga menjadikan masalah "menurunkan pakaian" sebagai bagian dari syiar Islam dan kefarduannya. Akibatnya, apabila melihat orang alim atau dai yang tidak menurunkan pakaiannya, seperti yang mereka sendiri mengenakannya, maka mereka akan menudingnya, baik secara samar maupun terang-terangan sebagai orang yang dangkal dalam urusan agama. Padahal, apabila mereka mau membahas sejumlah hadis yang berkaitan dengan masalah ini, kemudian mengakomodir antara beberapa hadis tersebut secara komprehensif, niscaya mereka akan mengetahui apa sebenarnya yang dimaksud oleh hadis-hadis itu. Sebagai akibatnya, mereka akan meredakan sikap ekstrimnya dan tidak terseret terlalu jauh dari kebenaran, serta tidak akan mempersempit sesuatu yang sebenarnya telah dipermudah oleh Allah SWT. bagi manusia. ${ }^{28}$

\footnotetext{
${ }^{27}$ Ibid., h. 125.

${ }^{28}$ Ibid., h. 125.
} 
Dalam sebuah hadis yang diriwayatkan oleh Muslim dari Abû Dzar r.a, bahwa Nabi SAW. bersabda:
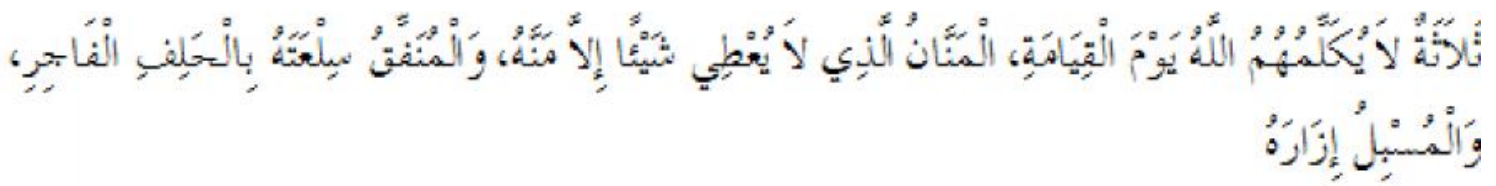

Tiga kelompok manusia yang tidak akan diajak bicara oleh Allah SWT. di hari kiamat kelak: seorang mannan (pemberi) yang tidak memberi sesuatu kecuali untuk diungkit-ungkit, seorang pedagang yang berusaha melariskan barang dagangannya dengan mengucapkan sumpahsumpah palsu, dan seorangyang menjulurkan sarungnya sampai di bawah kedua mata kaki" (H.R. Muslim). ${ }^{29}$

Akan tetapi, berlandaskan pengkajian terhadap sejumlah hadis yang berhubungan dengan pembahasan ini, akan nampak jelas pendapat yang dikuatkan oleh Imam al-

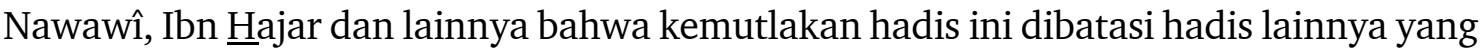
menyertakan sebab adanya ancaman, yakni karena kesombongan. ${ }^{30} \mathrm{Di}$ antaranya hadis yang diriwayatkan oleh al-Bukhârî dari 'Abdullâh Ibn 'Umar bahwa Nabi SAW. bersabda:

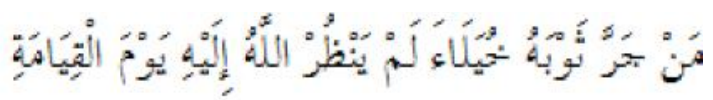

Barang siapa yang menyeret kainnya karena didasari sikap sombong, maka Allah tidak akan melihatnya di hari kiamat" (H.R. al-Bukhârî). ${ }^{31}$

Imam Muslim meriwayatkan sejumlah hadis yang membahas tentang masalah "menjulurkan sarung" dari Abû Hurairah dan Ibn 'Umar melalui jalur sanad yang beragam. Di antaranya adalah bahwa ia mendengar Rasulullah bersabda "barangsiapa menjulurkan sarungnya dengan tujuan hanya menyombongkan diri, maka Allah SWT. tidak akan melihatnya di hari kiamat". ${ }^{32}$ Secara sharîh hadis tersebut membatasi kemutlakan hadis yang memuat larangan menjulurkan sarung sampai di bawah mata kaki.

Ibn Hajar menyatakan ketika mensyarahi hadis yang berkenaan dengan "menjulurkan sarung dan ancaman bagi pelakunya", bahwa menjulurkan sarung karena didasari rasa sombong adalah dosa besar. Begitu pula, menurut literal hadis dihukumi haram menjulurkan sarung sekalipun tidak dilandasi sikap angkuh. Akan tetapi, menurut penilaian Ibn $\underline{\text { Hajar }}$

\footnotetext{
${ }^{29}$ al-Yahshabî, Ikmâl al-Mu'lim bi Fawấidi Muslim, Juz I, h. 381; al-Qurthubî, al-Muhlim limâ Asykala min Talkhîsh Kitâb Muslim, Juz I, h. 303; al-Nawawî, Shahîh Muslim bi Syarhí al-Nawawî, Juz II, h. 114; Mûsâ Syâhin Lâsyin, Fath1 al-Mun'im Syarh Shahîh Muslim, Juz I, h. 347.

${ }^{30}$ Al-Qasthalânî, Irsyâd al-Sârî ilâ Syarhii Shahîh al-Bukhârî, Juz VIII, h. 418; Ibn Hajar al-'Asqalânî, Fath al-Bârî Syarh al-Bukhârî, Juz X, h. 269; Mûsâ Syâhin Lâsyin, Fath al-Mun'im Syarh Shahîh Muslim, Juz I, h. 347.

${ }^{31}$ Al-Suyûthî, al-Tausyîkh Syarh al-Jâmi' al-Shahîh $\underline{h}$, Juz VIII, h.3563; 'Iyâdh Ibn Mûsâ Ibn 'Iyâdh al-Yahshabî, Ikmâl al-Mu'lim bi Fawầ 'idi Muslim, Juz I, h. 381.

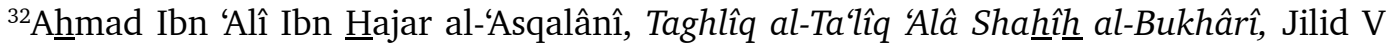
(Yordania: Dâr 'Imâr, 1985), h. 55.
} 
hadis yang melarang "menjulurkan sarung" diarahkan pada hadis yang dibatasi dengan adanya rasa sombong. Oleh karenanya, "menjulurkan sarung" tidak dihukumi haram jika bukan karena sombong. ${ }^{33}$

\section{Mengkompromikan atau Menarjîh Hadis-Hadis yang Kontradiktif}

Pada prinsipnya, nash-nash syariat tidak mungkin saling bertentangan satu sama lain. Kendatipun ditemukan nash yang saling bertentangan, maka pertentangan itu sebatas zhâhir saja bukan secara substansi. Dalam menyelesaikan masalah hadis yang nampak bertentangan, Yûsuf al-Qardhâwî mengemukakan untuk mengkompromikan terlebih dahulu sekiranya kandungan sejumlah hadis dapat diamalkan. Tetapi, jika tidak memungkinkan untuk dikompromikan, maka dapat menempuh cara pen-tarjîh $\underline{h}$-an terhadap salah satu hadis. ${ }^{34}$

Salah satu cara yang penting untuk memahami Sunnah dengan baik adalah mengkompromikan hadis-hadis sahih yang nampak bertentangan, kemudian menggabungkan antara hadis yang satu dengan hadis yang lainnya serta memposisikan masing-masing hadis sesuai dengan tempatnya, sehingga menjadi saling menyempurnakan dan tidak nampak bertolakbelakang dan berparadoks. ${ }^{35}$

Contoh hadis yang diketengahkan oleh Yûsuf al-Qardhâwî adalah hadis tentang ziarah kubur bagi wanita. Hadis dari Abû Hurairah,

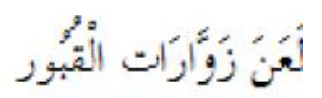

Bahwa Rasulullah SAW. melaknat wanita yang sering menziarahi kuburan (H.R. Ahmad, Ibn Majah dan al-Turmudzî). ${ }^{36}$

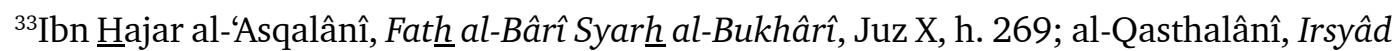
al-Sârî ilâ Syarh Shahîh al-Bukhârî, Juz VIII, h. 418.

${ }^{34}$ Metode yang ditempuh Yûsuf al-Qardhâwî searus dengan metode yang dirumuskan oleh jumhur ulama dalam menyelesaikan perbenturan antara dua atau pun beberapa dalil, yaitu: pertama, al-Jam'u wa al-taufíq baina al-muta'âridhaini bi wajhin maqbâl (mengumpulkan dan mengkompromikan dalil-dalil yang bertentangan sekalipun dari satu sisi), kedua, al-tarjîh, ketiga, al-nasakh dan pemungkas, tasâqud al-dalilain. Lihat pendapat-pendapat ini beserta dalil-dalilnya dalam, 'Abdurrahmân, Taisîr al-Wushûl ilâ Minhâj al-Ushûl min al-Manqâl wa al-Ma'qâl, Juz VI, h. 193; Jalâluddîn al-Suyûthî, Syarh al-Kaukab al-Sâthi', Juz II (Kairo: Maktabah al-Imân, 2002), h. 363; Muhammad Ibn Aḥmad Ibn 'Abd al-Azîz, Syarh al-Kaukab al-Munîr, Jilid IV (Riyâdh: Maktabah al-Abikân, 1993), h. 609: al-Thâfî, Syarh Mukhtashar al-Raudhah, Juz III, h. 687; al-Zarkasyî, alBahru al-Muhîth fĩ Ushûl al-Fiqh, Juz VI, h. 133; al-Dabakhsyî, Manâhij al-'Uqûl, Juz III, h. 157;

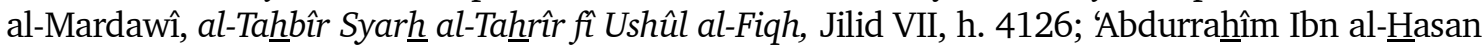
al-Asnawî, al-Tamhîd fĩ Takhrîj al-Furâ' 'alâ al-Ushûl (Beirut: Mu' assasah al-Risâlah, 1981), h.

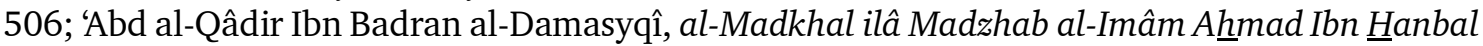
(Beirut: Mu` assasah al-Risâlah, 1981), h. 396; Muhammad al-Amîn Ibn Aḥmad Zaidan, Marâqî alSu'âd ilâ Marâqî al-Suyâd (Kairo: Maktabah Ibn Taimiyah, 1993), h. 412.

35Yûsuf al-Qardhâwî, Kaifa Nata'âmal ma'a al-Sunnah al-Nabawiyyah, h. 135.

${ }^{36}$ Al-Subkî, al-Manhal al-Adzbu al-Maurâd, Juz IX, h. 102; Muhammad al-Muntaqî al-Katsnawî 
Hadis tersebut dikuatkan pula oleh sejumlah hadis yang memuat larangan bagi wanita untuk mengikuti jenazah. Dengan pendekatan fahwal khithâb, maka dapat diambil suatu pemahaman mengenai larangan terhadap wanita untuk berziarah kubur. Akan tetapi, terdapat hadis-hadis lainnya yang kandungan materinya menganjurkan dan memberi izin bagi kaum wanita untuk menziarahi kuburan, sama seperti kaum laki-laki. Di antaranya, sabda Nabi SAW.:

$$
\text { كنت فيتكم عن زيارة القبور, فزورها }
$$

Aku pernah melarang kalian menziarahi kuburan, sekarang ziarahilah atau ziarahilah kuburankuburan, sebab itu akan mengingatkan kepada kematian (H.R. Ahmad, Ibn Majah dan alTurmudzî). ${ }^{37}$

Dalam hadis lainnya, diriwayatkan dari Imam Muslim bahwa Nabi bersabda:

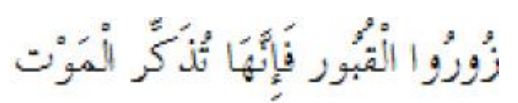
......Ziarahilah kuburan-kuburan, sebab hal itu akan mengingatkan kepada kematian (H.R. Muslim). ${ }^{38}$

Selain itu, ada sejumlah hadis yang berisi kebolehan wanita menziarahi kuburan yang diriwayatkan dari berbagai mata rantai sanad. Di antaranya diriwayatkan oleh Muslim,

al-Kumâsî, al-Kaukab al-Wahhâjah, Juz II (Beirut: Dâr al-Arabiah, 1988), h. 620; Muhammad Ibn Alî Ibn Muhammad al-Syaukânî, Nail al-Authâr Syarh Muntaqâ al-Akhbâr, Juz IV (Mesir: Mathba'ah Mushthafâ al-Bâbî al-Halabî, t.t.), h. 125; Muhammad 'Abd al-Rahmân Ibn 'Abd al-Rahîm alMubârakfûrî, Tuhfah al-Ahwadzî bi Syarh Jâmi' al-Turmudzî, Juz IV (Beirut: Dâr al-Fikr, t.t.), h. 160; Muhammad Syamsul alIX (Madinah: al-Maktabah al-Salafiyah, 1969), h. 57; Ibn al-'Arabî al-Mâlikî, 'Arîdzah al-Ahwwadzî bi Syarh Shahîh $\underline{h}$ al-Turmudzî, Juz IV (Beirut: Dâr al-Kutub al-Ilmiah, t.t.), 276; Shâlih Ahmad alSyâmî, Zawâ 'idu al-Sunan, Juz II (Riyâdh: Dâr al-Nafâ' is, 1998), h. 600; 'Umar Ibn 'Alî Ibn Aḥmad al-Anshârî, al-Badru al-Munîr (Riyâdh: Dâr al-Hijrah, 2004) Jilid V, h. 345; Muhammad Ibn 'Abd al-Wâhid, al-Sunan wa al-Ahkkâm 'an al-Mushthafâ, Jilid III (Jeddah: Dâr Majîd 'Âsirî, 2004), h. 226; Muhammad Ibn 'Abdurrahmân al-Maghrawî, Fath al-Barri fí al-Tartîb al-Fiqhi (Riyâdh: Ma'mâ'ah al-Tuhaf al-Nafâ' is al-Dauliah, 1996) Jilid, VI, h. 533.

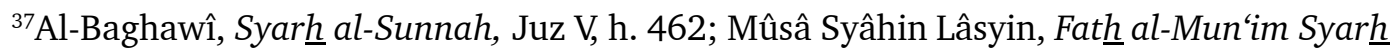

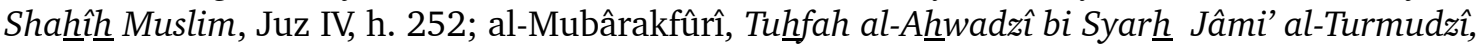
Juz IV, h. 159; al-'Azhîm 'Abûdî, 'Aunu al-Ma'bâd Syarh Sunan Abî Daud, Juz IX, 59; al-Anshârî, al-Badru al-Munîr, Jilid V, h. 341.

${ }^{38} \mathrm{Al}$-Qurthubî, al-Muhlim limâ Asykala min Talkhîsh Kitâb Muslim, Juz II, h. 633; Abdurrahmân Ibn Abu Bakar al-Suyûthî, al-Dîbâj 'alâ Shahîh Muslim Ibn Hijâj, Juz III (Riyâdh: Dâr Ibn 'Affân, 1996), h. 46; al-Mubârakfûrî, Minnah al-Mun'im fí Syarh Shahîh $\underline{h}$ Muslim, Juz II, h. 78; al-Anshârî, al-Badru al-Munîr, Jilid V, h. 342; Muhammad Ibn 'Abd al-Wâhid, al-Sunan wa al-Ahkkâm 'an alMushthafâ, Jilid III, h. 224. Hadis ini menasakh larangan dan menerangkan 'illat kebolehan menziarahi kuburan, di mana tujuannya untuk mengingat mati, bukan membanggakan diri dan terus meratapinya. Al-Yahshabî, Ikmâl al-Mu’lim bi Fawâ ’ idi Muslim, Juz III, h. 452; al-Wasytânî, Ikmâl Akmal al-Ma'lam, Juz III, h. 106; alV, h. 463; al-Syaukânî, Nail al-Authâr Syarh Muntaqâ al-Akhbâr, Juz IV, h. 124; al-Maghrawî, Fath al-Barri fi al-Tartib al-Fiqhi, Jilid VI, h. 532. 
al-Nasâ̂î dan Ahmad, dari 'Aisyah berkata:” Apa yang harus ku ucapkan kepada mereka, ya Rasulullah?" (yakni apabila aku menziarahi kuburan). Jawab beliau "Katakanlah: 'Salam sejahtera atas kaum Mukmin dan Muslim, para penghuni rumah-rumah ini. Semoga Allah merahmati semua kita, yang telah mendahului maupun yang masih tertinggal. Kami insyaAllah - akan menyusul kalian." ${ }^{39}$

Kendatipun hadis-hadis yang menunjukkan diizinkannya bagi "wanita menziarahi kuburan" lebih sahih dan lebih banyak dibandingkan hadis-hadis yang mengindikasi larangan. Namun, menggabungkan dan mengkompromikan semua kandungan hadis masih mungkin diupayakan, yaitu dengan membawa kata "melaknat" dalam hadis tersebut dialamatkan kepada para wanita yang sering melakukan ziarah. Sebagaimana diutarakan oleh al-Qurthubî. Karena kata "zawwarat” berbentuk mubâlaghah yang berkonotasi makna "sering sekali". Menurut al-Qurthubî, barangkali sebab larangan tersebut adalah hal itu dapat berakibat mengabaikan pemenuhan hak para suami, menyeret mereka pada perbuatan tabarruj serta meratapi orang-orang mati dengan suara lantang dan kemungkinan lainnya. Sebaliknya, jika semua sebab itu dapat dihindarkan, maka tidak ada mâni' (penghalang) memberi izin kepada mereka. Karena perkara mengingat mati adalah sesuatu yang diperlukan bagi laki-laki dan wanita. ${ }^{40} \mathrm{Al}$-Syaukânî berkata "pendapat inilah yang sepantasnya dijadikan pedoman dalam upaya penggabungan antara hadis-hadis yang secara zhâhir nampak saling bertentangan." ${ }^{41}$ Apabila tidak mungkin menggabungkan antara dua hadis atau berbagai hadis yang pada zhâhirnya saling bertentangan, barulah diupayakan pen-tarjîh $\underline{\text { - }}$ an, yaitu dengan mentarjihkan salah satu darinya, dengan berbagi alasan pen-tarjîh $\underline{h}$-an yang telah dirumuskan oleh para ulama. ${ }^{42}$

\section{Memahami Hadis dengan Memperhatikan Latarbelakang, Konteks dan Tujuannya}

Di antara metode yang baik untuk memahami hadis Nabi SAW. adalah dengan mengkaji sebab-sebab spesifik yang melatari munculnya sebuah hadis, atau keterkaitan dengan suatu 'illat tertentu, yang ditegaskan dalam hadis tersebut atau di-istinbath-kan

\footnotetext{
${ }^{39}$ Al-Qurthubî, al-Muhlim limâ Asykala min Talkhîsh Kitâb Muslim, Juz II, h. 635; al-Yahshabî, Ikmâl al-Mu'lim bi Fawấidi Muslim, Juz III, h. 449; al-Wasytânî, Ikmâl Akmal al-Ma'lam, Juz III, h. 104; al-Suyûthî, al-Dîbâj 'alâ Shahîh Muslim Ibn Hijâj, Juz III, h. 45; al-Subkî, al-Manhal al-

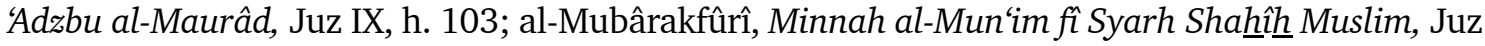
II, h. 77; Mûsâ Syâhin Lâsyin, Fathuu al-Mun'im Syarh Shahîh $\underline{h}$ Muslim, Juz IV, h. 252; al-Mubârakfûrî,

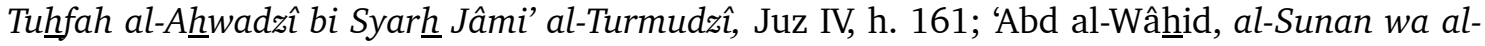
Ahkâm 'an al-Mushthafâ, Jilid III, h. 223.

${ }^{40}$ Al-Qurthubî, al-Muhlim limâ Asykala min Talkhîsh Kitâb Muslim, Juz II, h. 633; al-Subkî, al-Manhal al-Adzbu al-Maurâd, Juz IX, h. 103; al-Syaukânî, Nail al-Authâr Syarh Muntaqâ al-Akhbâr,

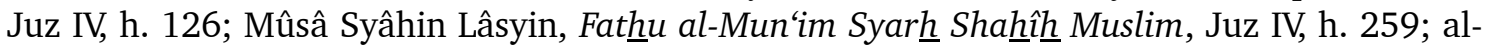
Mubârakfûrî, Tuhfah al-Ahwadzî bi Syarh Jâmi' al-Turmudzî, Juz IV, h. 160.

${ }^{41}$ Al-Syaukânî, Nail al-Authâr Syarh Muntaqâ al-Akhbâr, Juz IV, h. 126; al-Mubârakfûrî,

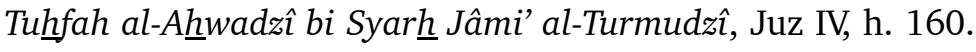

${ }^{42}$ Yûsuf al-Qardhâwî, Kaifa Nata'âmal ma'a al-Sunnah al-Nabawiyyah, h. 118.
} 
darinya, atau dapat juga dipahami dari peristiwa yang melingkupinya. Oleh karenanya, seseorang yang menkaji secara mendalam terhadap sebuah hadis, maka ia akan menemukan konteks dan sebab spesifik munculnya, sehingga mengetahui tujuan hadis tersebut disabdakan, yaitu untuk mewujudkan mashlahat, menampik mudharat dan menanggulangi problem yang terjadi pada waktu itu. ${ }^{43}$ Adakalanya hukum yang dikandung oleh suatu hadis tampak bersifat umum dan tidak berlimit waktu. Namun, jika dipikirkan secara mendalam, maka akan diketahui bahwa hukum tersebut dibangun atas suatu 'illat. Sebab itu, bila 'illat sudah hilang, maka hukum pun yang dikandungnya hilang, dan tetap berlaku jika 'illat masih layak diberlakukan. ${ }^{44}$

Untuk dapat memahami hadis dengan pemahaman yang benar dan tepat dibutuhkan pengetahuan situasi dan kondisi yang mengitari serta tujuan ia disabdakan. Dengan hal ini, makna yang dimaksudkan dari suatu hadis benar-benar diketahui dan terselamatkan dari berbagai praduga yang meleset dari tujuan yang sebenarnya. ${ }^{45}$ Ulama mengemukakan bahwa untuk memahami al-Qur'an secara benar adalah dengan mengetahui asbâb alnuzûl (sebab-sebab turunnya ayat-ayat al-Qur'an), ${ }^{46}$ sehingga tidak terjerumus pada kesalahan seperti halnya yang menimpa atas sebagian ektremis dari kelompok Khawârij dan lainnya. Mereka mengambil ayat-ayat yang turun berkaitan dengan orang-orang musyrik, kemudian menerapkannya pada orang-orang Muslim. Karena itu, bila asbâb al-nuzûl sangat penting diketahui dalam memahami atau menafsirkan al-Qur'an, maka asbâb al-wurûd (sebab-sebab yang mendasari disabdakan suatu hadis) lebih perlu lagi untuk diketahui. ${ }^{47}$

${ }^{43} I b i d .$, h. 147; Yûsuf al-Qardhâwî, Syarî’at al-Islâm Shâlihat li al-Tatbîq fî Kulli Makan wa Zamân (Kairo: Dâr al-Shahwah, 1993), h. 116.

${ }^{44}$ Ibid., h. 128.

${ }^{45}$ Menurut Yûsuf al-Qardhâwî menilai penting memperhatikan lima langkah dalam memahami sebuah Hadis, yaitu membedakan Hadis yang berlandaskan pada illat yang bersifat temporal dan universal. Jika 'illat itu sudah tiada, maka hukum yang dikandungnya juga tidak lagi dapat diberlakukan; membedakan Hadis yang bersandar pada 'urf dan tidak; membedakan Hadis yang berlaku secara universal pada seluruh orang mukallaf dan Hadis yang bersifat spesifik pada daerah dan kelompok tertentu; membedakan antara perkataan dan perbuatan yang muncul dari baginda Nabi dalam kapasitasnya sebagai Pemimpin, Pemberi fatwa atau Rasulullah; membedakan antara Hadis yang diperuntukkan pada suatu peristiwa dalam keadaan tertentu dan Hadis yang berlaku secara universal dan eternal. Ibid., h. 116

${ }^{46}$ Sekurang-kurangnya ada dua argumen keharusan mengetahui asbâb al-nuzûl, yaitu: pertama, kemukjizatan al-Qur'ân tidak mungkin bisa dipahami, melainkan dengan mengetahui seputar konteks yang mengelilinginya ketika ia diwahyukan, baik terkait dengan teks itu sendiri, mukhâthab (yang dikenai sasaran) dan mukhâthib (penyampai khithâb). Karena suatu perkataan melahirkan pemahaman yang berbeda sesuai dengan konteks yang melingkupinya. Seperti kata istifhâm (pertanyaan) adakalanya menunjukkan penegasan atau pelecehan, dan kata amr (perintah) terkadang mengindikasikan ancaman, pelemahan dan kebolehan. Kedua, minimnya pengetahuan asbâb al-nuzûl menjerumuskan pada kekaburan dan kesalahpahaman dalam mengungkap makna suatu teks. Wahbah al-Zuhailî, Ushûl al-Fiqh al-Islâmî, Juz I, h. 427; Muhammad al-Khudharî Bek, Ushûl al-Fiqh, h. 210.

${ }^{47}$ Yûsuf al-Qardhâwî, Kaifa Nata'âmal ma'a al-Sunnah al-Nabawiyyah , h. 148. 
Sementara itu, karakteristik al-Qur'an bersifat universal dan eternal. Karenanya, ia tidak butuh menjelaskan hal-hal secara parsial, terperinci dan terikat dengan waktu tertentu. Melainkan ia menghadirkan prinsip-prinsip tertentu atau ungkapan yang dapat ditarik suatu 'ibrah (pelajaran) ${ }^{48}$ Sedangkan, al-Sunnah diutarakan untuk menangani berbagai problem yang bersifat kasuistik (al-maudhû'iah), parsial (al-juz 'iah) dan temporal (al- 'âniât). Di samping itu, al-Sunnah juga memuat hal-hal yang spesifik dan terperinci, yang tidak terdapat dalam al-Qur'an. Karena itu, sangat penting melakukan pemilahan antara hadis yang bersifat spesifik dan universal, temporal dan eternal, serta yang partikular dan global. Setelah itu, memposisikan bagian masing-masing sesuai dengan ketentuannya. Dengan memperhatikan konteks, kondisi serta sebab-sebab (asbâb al-nuzûl maupun asbâb al-wurûd) dapat mempermudah dalam memperoleh pemahaman yang benar dan lurus. ${ }^{49}$

Terkait dengan metode ini, Yûsuf al-Qardhâwî menampilkan hadis yang diriwayatkan secara marfü‘ oleh al-Bukhârî dan Muslim dari Ibn 'Abbâs, bahwa Nabi SAW. bersabda:

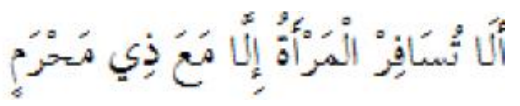

Tidak boleh seorang perempuan bepergian kecuali ada mahram bersamanya (H.R. al-Bukhârî dan Muslim). ${ }^{50}$

'Illat larangan ini adalah kekhawatiran akan keselamatan perempuan bilamana ia berpergian tanpa dibarengi suami atau mahram. Waktu itu alat kendaraan mengunakan unta, baghal atau keledai, mengarungi padang pasir dan padang sahara yang sepi dari hunian penduduk. Suasana sepi seperti itu, bisa mengancam keselamatan perempuan, atau setidak-tidaknya dapat mencemari dan mencoreng nama baiknya. Akan tetapi, jika kondisinya telah berubah, alat transportasi sudah canggih dan bisa dipenuhi banyak orang, semisal pesawat terbang yang memuat seratus orang penumpang atau lebih, atau kereta api yang bisa diisi ratusan orang, maka tidak ada persoalaan bagi perempuan bepergian sendiri dan ini tidak dianggap sebagai bentuk penyimpangan terhadap hadis tersebut. ${ }^{51}$

${ }^{48}$ Penjelasan al-Qur'an bersifat universal dan global, tidak secara parsial dan terperinci. Hal ini merupakan karakteristik syariat Islam yang elastis, komprehensif dan universal supaya ia bisa mengcover kebutuhan umat manusia disetiap tempat dan sepanjang masa. Di samping itu, syariat Islam selalu dapat selaras dan sesuai perkembangan dan kemajuan masa dengan upaya terjewantahnya kemashlahatan di tengah-tengah masyarakat. Wahbah al-Zuhailî, Ushûl al-Fiqh al-Islâmî, Juz I, h. 424.

${ }^{49}$ Yûsuf al-Qardhâwî, Kaifa Nata'âmal ma'a al-Sunnah al-Nabawiyyah, h. 127.

${ }^{50}$ Al-Qasthalânî, Irsyâd al-Sârî Ilâ Syarh Shahîh $\underline{h}$ al-Bukhârî, Juz III, h. 324; 'Alî Ibn Khalaf Ibn 'Abd al-Mulk, Syarh Shahîh al-Bukhârî, Juz IV (Riyâdh: Maktabah al-Rusy, t.t.), 531; al-Subkî, al-Manhal al-Adzbu al-Maurâd, Juz X, h. 264; al-Baghawî, Syarh al-Sunnah, Juz VII, h. 18; al'Ainî, 'Umdah al-Qârî Syarh Shahîh al-Bukhârî, Juz X, h. 315; al-'Azhîm Abûdî, 'Aunu al-Ma'bâd Syarh Sunan Abî Daud, Juz V, h. 149; Mûsâ Syâhin Lâsyin, Fathuu al-Mun'im Syarh Shahîh $\underline{h}$ Muslim, Juz V, h. 391; al-Mubârakfûrî, Minnatu al-Mun'im fi Syarhi Shahîh Muslim, Juz II, h. 338; al-Suyûthî, al-Tausyikh Syarh al-Jâmi' al-Shahîhn, Juz IV, h. 1395; al-Yahshabî, Ikmâl al-Mu’lim bi Fawâ 'idi Muslim, Juz IV, h. 450.

${ }^{51} Y$ ûsuf al-Qardhâwî, Kaifa Nata'âmal ma'a al-Sunnah al-Nabawiyyah, h. 151. 
Sebagian Imam membolehkan perempuan pergi berhaji dengan tanpa dibarengi suami atau mahram, bilamana mereka bersama dengan sejumlah perempuan yang bisa dipercaya ataupun rombongan yang dipercaya. ${ }^{52}$ Pada masa kekhalifahan 'Umar, pernah suatu waktu 'Aisyah dan istri Nabi yang lain melakukan perjalanan untuk berhaji tanpa disertai seorang mahram pun, mereka hanya ditemani 'Ustmân Ibn 'Affân dan 'Abdurrahmân Ibn 'Auf yang ditugasi untuk melayani mereka. ${ }^{53}$ Sebagian ulama juga membolehkan perempuan melakukan bepergian jika di jalan sudah tercipta keamanan. ${ }^{54}$

\section{Membedakan antara Instrumen yang Dinamis dan Tujuan yang Statis}

Di antara penyebab kekeliruan dan ketergelinciran dalam memahami al-Sunnah adalah mencampuradukkan antara maqâshid (tujuan-tujuan yang hendak direalisasikan) dengan instrumen atau sarana yang bersifat temporal dan lokalitas yang terkadang hanya sebagai penunjang pencapaian maqâshid tersebut. Dengan mengkaji maqâshid yang terkandung dalam al-Sunnah, maka menjadi jelas antara tujuan yang bersifat permanen dan eternal dengan sarana yang bisa mengalami perubahan sesuai dengan perubahan masa, lingkungan, kultur dan pengaruh-pengaruh lainnya. ${ }^{55}$

Perubahan yang terkait dengan instrumen atau sarana merupakan suatu keniscayaan. Sebab itu, apabila suatu hadis menerangkan sesuatu yang berkenaan dengan sarana tertentu, maka itu hanyalah untuk menjelaskan suatu fenomena. Namun, hal itu bukan dimaksudkan untuk membelenggu dan membekukan pikiran dengan penggunaan sarana itu. Bahkan, jika al-Qur'an sendiri menegaskan tentang suatu sarana yang relevan dengan tempat dan masa tertentu, hal itu bukan berarti harus stagnan, dan tidak memikirkan

${ }^{52}$ Al-Qasthalânî, Irsyâd al-Sârî Ilâ Syarh Shahîh al al-Bukhârî, Juz III, h. 326. Imam Mâlik, imam Syâfiî̀ dan al-Auza'î menyatakan perempuan diperkenankan bepergian untuk melaksanakan haji wajib, sekalipun tidak bersama mahramnya, jika disertai dengan beberapa perempuan lain dan berada dalam rombongan yang dapat dipercaya. 'Abd al-Mulk, Syarh Shahîh al-Bukhârî, Juz IV, 532; al-Bâjî, al-Muntaqâ Syarh Muwattha' Mâlik (Beirut: Dâr al-Kutub al-'Ilmiah, 1999) Juz

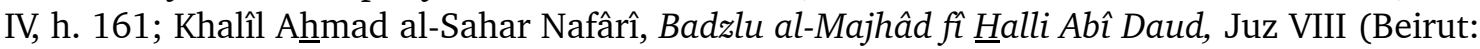
Dâr al-Kutub al-Ilmiah, t.t.), h. 303; al-Baghawî, Syarh al-Sunnah, Juz VII, h. 20; al-Nawawî, Shahîh Muslim bi Syarhi al-Nawawî, Juz IX, h. 104; al-'Azhîm 'Abûdî, 'Aunu al-Ma'bâd Syarh1 Sunan Abî Daud, Juz V, h. 150; Mûsâ Syâhin Lâsyin, Fathu al-Mun'im Syarh Shahîh1 Muslim, Juz V, h. 396.

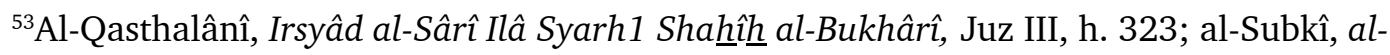
Manhal al-'Adzbu al-Maurâd, Juz X, h. 268; al-'Azhîm Abûdî, 'Aunu al-Ma'bâd Syarh Sunan Abî Daud, Juz V, h. 147.

54‘Athâ', Sa’îd Ibn Jâbir, Ibn Sirîn, Mâlik, al-Auzâ̂î dan al-Syâfi'î menyatakan adanya mahram bukan suatu syarat, tetapi terciptanya rasa aman pada diri perempuan itulah yang subtansi di balik persyaratan mahram. al-'Azhîm Abûdî, 'Aunu al-Ma’bâd Syarh Sunan Abî Daud, Juz V, h. 150; Mûsâ Syâhin Lâsyin, Fath al-Mun'im Syarh Shahîh $\underline{h}$ Muslim, Juz V, h. 396.

${ }^{55}$ Yûsuf al-Qardhâwî, Kaifa Nata'âmal ma'a al-Sunnah al-Nabawiyyah, h.161. 
mengenai sarana-sarana lain yang lebih relevan dan berkembang sejalan perkembangan zaman. $^{56}$

Contoh hadis yang terkait dengan metode ini adalah hadis yang diriwayatkan oleh

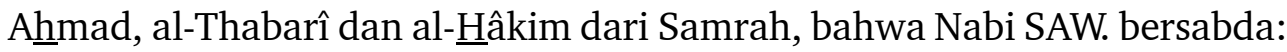

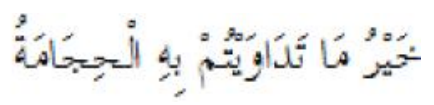

Sebaik-baik sesuatu untuk kamu berobat adalah bekam (H.R. Ahmad, al-Tabrani dan alHâkim)..$^{57}$

Hadis di atas menginformasikan bahwa berbekam adalah obat terbaik. Berbekam merupakan sarana untuk menyehatkan tubuh. Tetapi, jika ditemukan obat yang lebih baik daripada bekam, maka ia bukan lagi obat terbaik dan temuan ini bukan berlawanan dengan isi hadis. Menurut al-Qardhâwî, resep bekam dan semacamnya itu bukanlah substansi pengobatan Nabi (al-Thib al-Nabawi). Melainkan substansinya adalah memelihara kesehatan dan kehidupan manusia, keselamatan dan kebugaran tubuh. Selain itu, untuk memenuhi hak tubuh dalam beristirahat di saat lelah dan berobat dikala sakit. Berobat tidak menafikan keimanan pada takdir ataupun tawakkal pada Allah SWT. Subtansi hadis tersebut juga mengisyaratkan bahwa setiap penyakit ada obatnya, mengikuti sunnatullah, menaruh kepedulian pada kebersihan tubuh, rumah, jalan, larangan mencemari air dan bumi serta tujuan-tujuan lain yang selaras dengan laju kemajuan zaman.

Hadis lain yang diangkat oleh al-Qardhâwî adalah hadis tentang siwak:

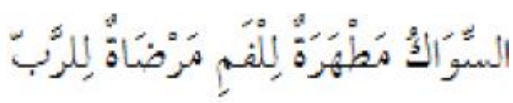

Siwak dapat membersihkan mulut serta keridaan Tuhan (H.R. al-Bukhârî). ${ }^{58}$

Berhubungan dengan hadis ini, al-Qardhâwî mengemukakan siwak merupakan sarana dan tujuannya adalah membersihkan gigi dan menghilangkan bau mulut. Karena itu, tidak dipersoalkan menggunakan alat lainnya yang berfungsi sama dengan siwak meskipun tidak terbuat dari kayu arak. Dengan ini, diketahui bahwa sikat gigi dan pasta gigi (seperti yang dikenal sekarang) sepenuhnya dapat menggantikan kayu arak. Terutama dipakai di rumah, setelah makan, atau ketika hendak tidur. ${ }^{59}$

${ }^{56}$ Ibid., h. 162.

${ }^{57}$ Al-Qurthubî, al-Muhlim limâ Asykala min Talkhîsh Kitâb Muslim, Juz IV, h. 453 ; al-Yahshabî,

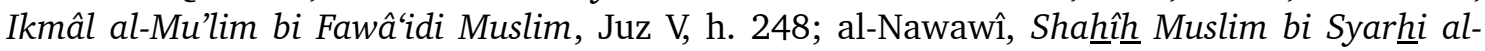
Nawawî, Juz X, h. 242.

${ }^{58}$ Al-Suyûthî, al-Tausyîkh Syarh al-Jâmi’ al-Shahîhn, Juz IV, h. 1438; al-'Asqalânî, Taghlîq al-Ta'lî̀ 'Alâ Shahîh $\underline{h}$ al-Bukhârî̀, Jilid III, h. 165; al-Qasthalânî, Irsyâd al-Sârî Syarh Shahîh alBukhârî, Juz III, h. 373; 'Abd al-Mulk, Syarh Shahîh al-Bukhârî, Juz IV, h. 63; al-'Ainî, 'Umdatu

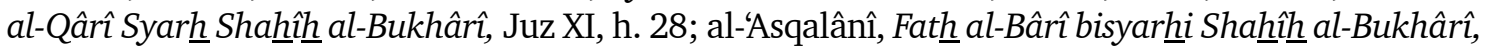
Juz IV, h. 187.

${ }^{59} Y$ ûsuf al-Qardhâwî, Kaifa Nata'âmal ma'a al-Sunnah al-Nabawiyyah, h.163. 
MIQOT Vol. XXXIX No. 2 Juli-Desember 2015

\section{Membedakan antara Lafaz Hakikat dan Lafaz Majâz}

Bahasa Arab memiliki keunikan tersendiri menyangkut ungkapan dalam bentuk majâz (metafora). Ungkapan dalam bentuk majâz lebih memberi kesan daripada perkataan dalam bentuk hakikat, sebagaimana diterangkan dalam ilmu balâghah. Sementara itu, Rasulullah adalah seorang yang lihai dalam mengungkapkan kata-kata yang ber-balâghah. Sabda-sabdanya adalah bagian dari yang diwahyukan, maka tidak mengherankan bilamana dalam sejumlah hadis-hadisnya terdapat kata-kata majâz. Beliau menggunakan kata majâz untuk mengutarakan maksudnya dengan ungkapan yang mengesankan. Adapun yang dimaksud majâz di sini mencakup majâz lughawî, 'aqli, isti'ârah, kinâyah dan setiap kata atau kalimat yang keluar dari dalâlah (penunjukan) yang sebenarnya. Ungkapan dalam bentuk majâz hanyalah dapat dimengerti dengan melihat indikasi yang menyertainya, baik yang bersifat tekstual (maqâliah) maupun kontekstual (hâliah) ${ }^{60}$

Bahkan dalam kondisi tertentu, membawa pemahaman berdasarkan majâz merupakan suatu keharusan. Sebab, jika tidak dipahami dalam makna majâz dapat berakibat salah pemahaman dan menjerumuskan pada kekeliruan. Dalam konteks ini, ketika Rasulullah SAW. berkata kepada istri-istrinya:

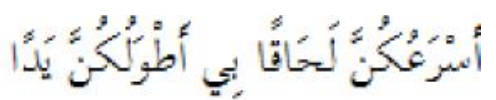

Yang paling cepat menyusulku diantara kalian-sepeninggalku-adalah yang paling panjang tangannya (H.R. Muslim). ${ }^{61}$

Mereka memahami yang dimaksud adalah orang yang paling panjang tangannya secara hakikat. Karena itu, seperti yang dikatakan 'Aisyah ra. mereka saling mengukur, siapa di antara mereka yang tangannya paling panjang? Bahkan, menurut sebagian hadis menerangkan bahwa mengambil sebatang bambu untuk dibuat alat ukuran siapakah tangan yang paling panjang. ${ }^{62}$

Padahal, Rasulullah SAW. tidak bermaksud demikian. Hanyalah yang dimaksud dengan ungkapan beliau "tangan yang paling panjang" adalah yang paling banyak kebaikan dan kedermawanannya. Sabda Nabi SAW. ini memang relevan dengan realita yang terjadi. Di antara istri-istri beliau yang pertama kali meninggal dunia setelah baginda

${ }^{60}$ Ibid., h.177.

${ }^{61}$ Al-Qurthubî, al-Muhlim limâ Asykala min Talkhîsh Kitâb Muslim, Juz VI, h. 360; alYahshabî, Ikmâl al-Mu'lim bi Fawâ'idi Muslim, Juz VII, h. 479; Mûsâ Syâhin Lâsyin, Fathu al-

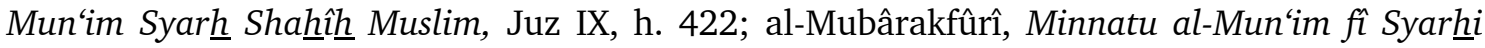

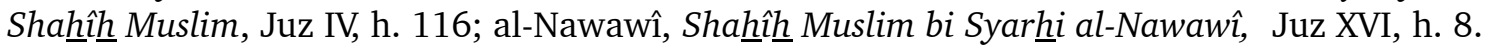

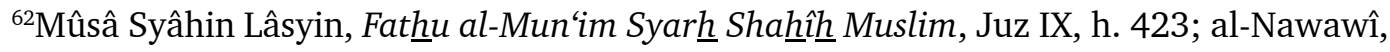
Shahîh Muslim bi Syarhi al-Nawawî, Juz XVI, h. 8. 
Nabi wafat adalah Zainab binti Jahsyi ra. Ia dikenal sebagai wanita yang senang bekerja dan terampil dengan kedua tangannya serta gemar bersedekah. ${ }^{63}$

\section{Membedakan antara Gaib (yang Misterius) dan Syahâdah (yang Realita)}

Di antara muatan isi hadis berkenaan dengan alam gaib, yang sebagiannya mengenai mahkluk yang tidak bisa dilihat di alam. Termasuk dalam kategori ini, misalnya malaikat, jin dan makhluk halus lainnya. Begitu pula, 'arasy, kursi, lauh al-mahfûzh dan qalam tidak dapat dilihat. Sebagian lagi dari hal-hal gaib ini berhubungan dengan kehidupan di alam barzah, yaitu kehidupan setelah mati dan sebelum datangnya hari kebangkitan. Misalnya, pertanyaan-pertanyaan malaikat di dalam kubur, kenikmatan atau siksaan di dalamnya. Selain itu, sebagiannya lagi berkaitan dengan kehidupan akhirat, misalnya kebangkitan dan pengumpulan manusia di padang mahsyar, kegentingan pada hari kiamat, syafâ'at 'uzhmâ, mîzan (neraca amalan manusia), hisâb, shirâth, surga dengan berbagai macam kenikmatan di dalamnya, baik yang bersifat materi maupun ruhiyah, tingkatantingkatan manusia di dalamnya, dan juga neraka serta beragam siksaan di dalamnya, baik yang bersifat inderawi ataupun maknawi, dan tingkatan-tingkatan manusia di dalamnya. ${ }^{64}$

Dalam persoalaan ini, seperti hadis yang diriwayatkan al-Bukhârî dan Muslim dari Sahl Ibn Sa‘d, Abi Sa‘id dan Abû Hurairah bahwa Nabi SAW. bersabda:

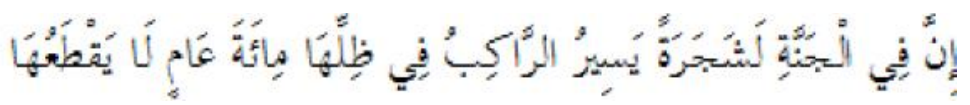

Di surga terdapat sebuah pohon yang jika seorang pengendara melewati di bawahnya selama seratus tahun, maka tidak cukup untuk menempuhnya (H.R. al-Bukhârî dan Muslim) ${ }^{65}$

Hadis tersebut diriwayatkan al-Bukhârî dan Muslim dari Sahl Ibn Sa‘d, Abû Sa‘̂̂d dan Abû Hurairah. Al-Bukhârî juga meriwayatkan dari Anas. Karena itu, ketika menafsirkan

${ }^{63}$ Al-Qurthubî, al-Muhlim limâ Asykala min Talkhîsh Kitâb Muslim, Juz VI, h. 360; Mûsâ

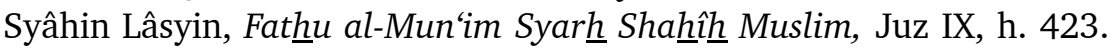

${ }^{64}$ Yûsuf al-Qardhâwî, Kaifa Nata'âmal ma'a al-Sunnah al-Nabawiyyah, h.193.

${ }^{65}$ Al-Nawawî, Shaĥîh Muslim bi Syarhi il-Nawawî, Juz XVII, h. 167; al-Mubârakfûrî, Minnatu

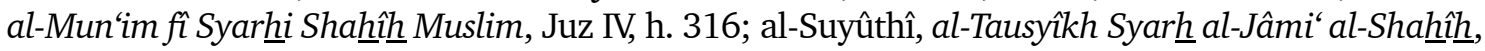
Juz V, h. 2111; al-Yahshabî, Ikmâl al-Mu'lim bi Fawâ 'idi Muslim, Juz VIII, h. 360; al-Qurthubî, al-Muhlim limâ Asykala min Talkhîsh Kitâb Muslim, Juz VII, h. 173; al-Suyûthî, al-Dîbâj 'alâ Shahîh Muslim Ibn al-Hijâj, Juz VI, h. 176; al-Wasytânî, Ikmâl Akmal al-Malam, Juz VII, h. 210;

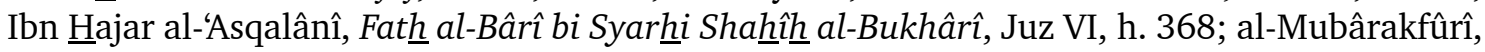
Tuhfah al-Ahwadzî bi Syarhi Jâmi' al-Turmudzî, Juz VII, h. 225. Ibn 'Abd al-Bar meriwayatkan secara marfû' dari Hadis 'Utbah ibn 'Abd al-Salmâ menyatakan pohon tersebut bernama Thâbâ, sejenis pohon kelapa. Seseorang bertanya pada Rasulullah, sebesar apa akarnya? Jawab Rasul: Seandainya kamu menunggangi unta hingga sangat lelah untuk berkeliling akar pohon itu, mesti tidak akan bisa menempuhnya. Dikatakan juga bahwa setiap rumah di surga muncul dari rantingrantingnya, burung-burung yang indah dan buah-buahan bersemi di dalamnya. al-'Aini, 'Umdatu

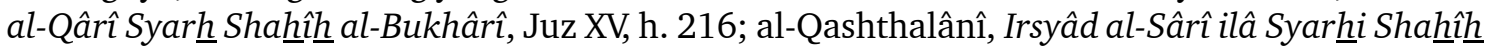
al-Bukhârî, Juz V, h. 284. 


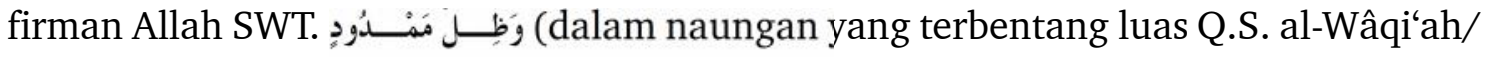
56: 30), Ibn Katsîr menyatakan bahwa hadis ini benar-benar datang dari Rasulullah, bahkan termasuk hadis mutawâtir yang qathî/pasti kesahihannya menurut penilaian para pakar hadis. ${ }^{66}$

Secara literal, yang dimaksud seratus tahun dalam hadis di atas adalah menurut tolak ukur tahun di dunia. Tidak ada yang mengetahui hakikat perbandingan antara waktu di dunia dan waktu di sisi Allah SWT., selain Allah SWT. Dalam al-Qur'an diterangkan:

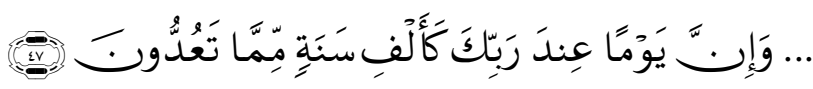

Dan sesungguhnya satu hari di sisi Tuhanmu seperti seribu tahun dalam perhitungan kalian (QS. al-Haj/22: 47).

Menurut al-Qardhâwî, apabila hadis tersebut sahih, hanya dapat dikatakan dengan penuh kemantapan hati, "kita percaya dan membenarkannya" seraya meyakini bahwa di akhirat terdapat aturan-aturan khusus yang berbeda dengan tatanan di dunia ini. Sebab itu, Ibn 'Abbâs menyatakan: Tidak ada di surga yang sama dengan di dunia melainkan langit! ${ }^{67}$

\section{Memastikan Makna Hadis dengan Melihat Madhûl/Konotasi Lafaz-Lafaznya}

Termasuk hal yang sangat penting dalam memahami hadis secara benar adalah memastikan makna yang dimaksud dalam hadis. Sebab, makna dari suatu kata dapat mengalami perubahan dari masa ke masa dan lingkungan pada lingkungan yang lain. Hal ini merupakan suatu yang sudah maklum menurut pakar bahasa, bahwa perubahan kata dan bahasa lantaran pengaruh zaman dan tempat di mana ia mengejala.

Terkadang suatu masyarakat menggunakan kata-kata untuk menunjukkan kepada makna-makna tertentu. Dalam konteks ini, tidak ada persoalaan sama sekali. Akan tetapi, yang dikhawatirkan di sini adalah apabila mereka menggiring kata-kata yang terdapat dalam al-Sunnah (dan dalam al-Qur'an) sesuai dengan istilah mereka yang baru. Di sinilah akan terjadi kerancuan dan kekeliruan. ${ }^{68}$

Seperti pemaknaan kata صـ صـ - صرyang banyak ditemukan dalam hadis-hadis sahih. Yang dimaksud dengan kata tashwîr dan mushawwir dalam hadis tersebut adalah menggambar dan penggambar yang ada bayang-bayangnya, dan sekarang dikenal dengan kata memahat dan pemahat. Inilah yang dimaksud makna tashwîr menurut ulama salaf dan disepakati para ulama mengenai keharamannya, selain untuk mainan anak-anak

\footnotetext{
t.t. ), h. 528.

${ }^{66}$ Ismâ'îl Ibn 'Umar Ibn Katsîr, Tafsîr al-Qur'ân al-Azhîm, Jilid VII (t.t.p.: Dâr Thayyibah,

${ }^{67}$ Yûsuf al-Qardhâwî, Kaifa Nata'âmal ma'a al-Sunnah al-Nabawiyyah, h. 196.

${ }^{68}$ Ibid., h. 199.
} 
kecil. ${ }^{69}$ Namun, sejalan dengan perkembangan bahasa, sebagian kelompok manusia mengartikan kata tashwîr dan mushawwir dengan memotret dan fotografer, yang dalam hadis akan diancam dengan ancaman yang sangat pedih.

Oleh karenanya, pemaknaan kata-kata tersebut tidak boleh dimaknai dengan makna yang berkembang sekarang, tetapi harus merujuk pada pemakaian makna yang dipahami masyakarat Arab sewaktu hadis tersebut disabdakan. Bidang fotografi ini belum ada dan tidak dikenal pada masa tasyri‘. Sebab itu, tidaklah tepat memasukkan fotografi dalam cakupan makna tashwîr, secara pemaknaan syara'. Dengan demikian, memotret dan fotografer tidak terkena dalam ancaman hadis tersebut. ${ }^{70}$

\section{Penutup}

Untuk menghasilkan pemahaman yang substantif dan komprehensif sesuai dengan spirit al-tasyrî‘, maqâshid al-syarî‘ah dan relevan dengan konteks kekinian ketika membaca dan mengkaji al-Sunnah, maka Yûsuf al-Qardhâwî menformulasikan delapan prinsip dasar. Pertama, memahami al-Sunnah sesuai dengan petunjuk al-Qur'an. Karena al-Sunnah diurutan kedua dalam pengistinbâthan hukum Islam, maka ia harus bersesuaian dengan sumber pertama dan utama hukum Islam, yaitu al-Qur'an. Kedua, mengumpulkan hadis-hadis yang satu tema bahasan. Sebab, terkadang terdapat sejumlah hadis yang menerangkan satu tema bahasan. Ada yang disertai dengan illat (alasan), ada yang tidak. Hal ini dibutuhkan mengumpulkan hadis-hadis tersebut supaya melahirkan pemahaman yang utuh. Ketiga, mengkompromikan atau men-tarjîh hadis-hadis yang kontradiktif. Metode ini penting untuk diimplementasikan ketika menemukan dua atau beberapa hadis yang kandungan materinya tidak seragam. Keempat, memahami hadis dengan memperhatikan latarbelakang, konteks dan tujuannya. Karena sebuah hadis muncul dilatarbelakangi suatu peristiwa dan sosial realitas yang mengitarinya. Pemahaman secara literal tanpa melihat konteks dan tujuan hadis tersebut disabdakan seringkali menjerumuskan pada kesalahpahaman dan keliru pemaknaan. Kelima, membedakan antara intrumen yang dinamis dan tujuan yang statis. Metode ini penting dilakukan karena untuk mengungkap tujuan yang esensial sebuah hadis, sehingga tidak terpaku pada intrumen tertentu. Keenam, membedakan antara lafaz hakikat dan lafaz majâz. Sebab, hanya dengan pendekatan

\footnotetext{
${ }^{69}$ Jumhur ulama dari kalangan sahabat, tabiin dan imam mazab, di antaranya al-Tsauri, Mâlik dan Abû Hanifah menghukumi haram terhadap pembuatan gambar hewan yang bisa digantung di dinding, pakaian, surban dan benda-benda berharga lainnya. Tetapi, dibolehkan pembuatan gambar tersebut pada permadani, bantal dan benda-benda remeh lainnya. Ulama juga sepakat mengenai larangan terhadap gambar/patung yang mempunyai bayangan dan menurut mereka wajib dirubahnya. Ibn 'Iyâdh berkata gambar/patung itu dilarang kecuali untuk mainan anak-anak perempuan, sebagai bentuk rukhsah bagi mereka. Mûsâ Syâhin Lâsyin, Fathu al-Mun'im

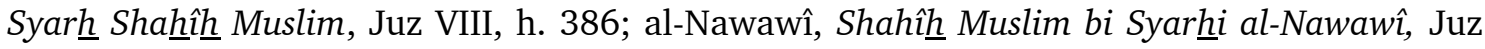
XIV, h. 81.

${ }^{70}$ Yûsuf al-Qardhâwî, Kaifa Nata'âmal ma'a al-Sunnah al-Nabawiyyah, h. 201.
} 
pemaknaan secara majâz terhadap hadis yang menggunakan lafaz majâz bisa dipahami secara benar dan tepat. Ketujuh, membedakan antara gaib (yang misterius) dan syahâdah (yang realita). Bila kandungan hadis sahih membicarakan tentang masalah yang gaib, maka umat Islam hanya dituntut mengimani dan meyakini dengan kemantapan hati. Kedelapan, memastikan makna hadis dengan melihat madhûl/konotasi lafaz-lafaznya. Sebab, makna dari suatu kata dapat mengalami perubahan dari lingkungan ke lingkungan yang lain, dan dari masa ke masa.

\section{Pustaka Acuan}

'Al-'Azîz, Muhammad Ibn Aḥmad Ibn Abd. Syarh al-Kaukab al-Munîr. Riyâdh: Maktabah al-Abikân, 1993.

Abâdî, Muhammad Syams al-ㅂaq al-'Azhîm. 'Aunu al-Ma'bûd Syarh Sunan Abî Daud. Madinah: al-Maktabah al-Salafiyah, 1969.

'Abd Allâh, Muhammad Ibn Bahâdir Ibn. Al-Bahru al-Muhîth fí Ushûl al-Fikih, cet. 2. Kuwait: Dâr al-Shafwah, 1992.

'Abd al-Wâhid, Muhammad Ibn. Al-Sunan wa al-Ahkkâm 'an al-Mushthafâ. Jeddah: Dâr Majî̀ “Âsirî, 2004.

'Abd al-Rah̆mân, Muhammad Ibn Muhammad Ibn. Taisîr al-Wushûl ilâ Minhâj al-Ushûl min al-Manqûl wa al-Ma'qûl. Kairo: al-Fârûq al-Hadisah, 2002.

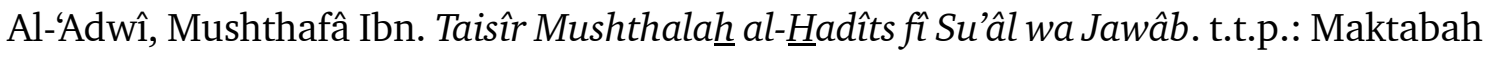
al-ㅍaramain, 1990.

Al-'Ainî, Mahnmûd Ibn Ah̆mad. 'Umdatu al-Qârî Syarh Shahîh al-Bukhârî. Beirut: Dâr alKutub al-Ilmiah, 2001.

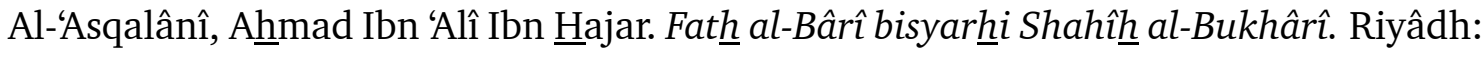
Maktabah al-Mulk, 2001.

Al-'Asqalânî, Ahmad Ibn 'Alî Ibn Hajar. Taghlîq al-Ta'lîq 'Alâ Sahîh $\underline{h}$ al-Bukhârî. Yordania: Dâr 'Imâr, 1985.

Al-Âmidî, 'Alî Ibn Muhammad. Muntahâ al-Sûl fị ‘Im al-Ushûl. Beirut: Dâr al-Kutub al'Ilmiah, 2003.

Al-Anshârî, 'Umar Ibn 'Alî Ibn Ahmad. al-Badru al-Munîr. Riyâdh: Dâr al-Hijrah, 2004.

Al-Anshârî, Muhammad Ibn Nizhâmuddîn Muhammad al-Sahalawî. Fawâtihh al-Rahamût. Beirut: Dâr al-Kutub al-'Tlmiah, 2002.

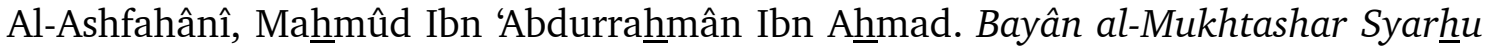

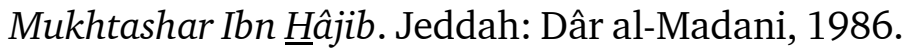

Al-Asnawî, 'Abdurrahîm Ibn al-Hasan. al-Tamhîd fí Takhrîj al-Furû' 'alâ al-Ushûl. Beirut: Mu`assasah al-Risâlah, 1981.

Al-Badakhsyî, Muhammad Ibn Hasan. Manâhij al-'Uqûl. Mesir: Mathba'ah Muhammad 'Alî Shâbih, t.t. 


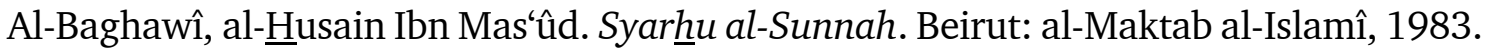

Al-Baidhâwî, 'Abd Allâh Ibn 'Umar. Nihâyah al-Sûl fî Syarhi Minhâj al-Ushûl. Beirut: Dâr al-Fikr, 1993.

Al-Bâjî̀, Sulaimân Ibn Khalaf Ibn Sa'ad Ibn Ayyûb. al-Muntaqâ Syarh Muwattha' Mâlik. Beirut: Dâr al-Kutub al-'Ilmiah, 1999.

Al-Bujairamî, Sulaimân bin Muhammad. Bujairamî 'alâ al-Khathîb. Beirut: Dâr al-Kutub al-'Ilmiah, 1996.

Al-Bukhârî, 'Abd al-'Azîz Ibn Aḥmad. Kasyf al-Asrâr 'an Ushûl Fakhri al-Islâm al-Bazdawî. Beirut: Dâr al-Kutub al-'Ilmiah, 1997.

Al-Dabûsî, 'Ubaidillâh Ibn 'Umar Ibn 'Isa. Taqwil al-Adillah fi Ushûl al-Fiqh. Beirut: Dâr al-Kutub al-'Ilmiah, 2001.

Al-Damasyqî, 'Abd al-Qâdir Ibn Badran. al-Madkhal ilâ Mazhab al-Imâm Ahmad Ibn Hanbal. Beirut: Mu`assasah al-Risâlah, 1981.

Al-Ghazâlî, Muhammad bin Muhammad. Al-Wasîth fì al-Mazhab. Kairo: Dâr al-Salâm, 1997.

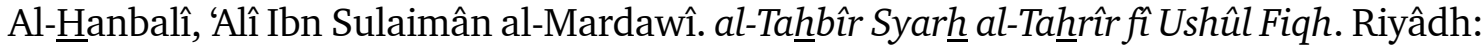
Maktabah al-Rusy, t.t.

Al-Jaizanî, Muhammad Ibn Husain Ibn Hasan. Ma'âlim Ushûl al-Fiqh 'inda Ahli al-Sunnah wa al-Jamâ'ah. Riyâdh: Dâr Ibn al-Jauzî, 1996.

Al-Jauziyah, Ibn Qayyim. I'lâm al-Muwaqqi'în 'an Rabb al-'Âlamîn. Riyâdh: Dâr Ibn alJauzî, $1423 \mathrm{H}$.

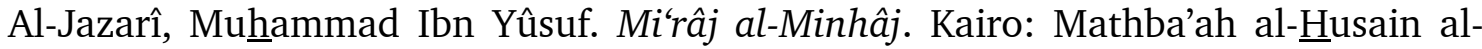
Islâmiah, 1993.

Al-Khabbâzî, 'Umar Ibn Muhammad Ibn 'Umar. Al-Mughnî fí Ushûl al-Fiqh. Jeddah: Dâr al-Madani, $1403 \mathrm{H}$.

Al-Khudharî Bek, Muhammad. Ushûl al-Fiqh. Mesir: al-Maktabah al-Tijâriyah al-Kubrâ, 1969.

Al-Kumâsî, Muhammad al-Muntaqî al-Katsnawî. al-Kaukab al-Wahhâjah. Beirut: Dâr al-Arabiah, 1988.

Al-Maghrawî, Muhammad Ibn 'Abd al-Rahmân. Fath al-Barrifí al-Tartîb al-Fiqhi. Riyâdh: Ma'mû'ah al-Tuhaf al-Nafâ 'is al-Dauliah, 1996.

Al-Majdzûb, Muhammad. 'Ulamấ' wa Mufakkirûn 'Araftuhum. Beirut: Dâr al-Nafầis, 1977.

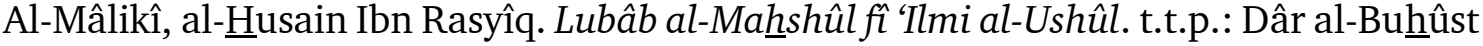
li al-Dirâsât al-Islâmiah wa Ihyâ' al-Turâts, 2001.

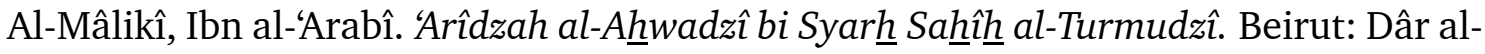
Kutub al-'Ilmiah, t.t.

Al-Mubârakfûrî, Muhammad 'Abdurrahmmân Ibn 'Abdurrahîm. Tuḩfah al-A $\underline{h} w a d z i ̂ ~ b i ~ S y a r h \underline{~}$ Jâmi' al-Turmudzî. Beirut: Dâr al-Fikr, t.t. 
MIQOT Vol. XXXIX No. 2 Juli-Desember 2015

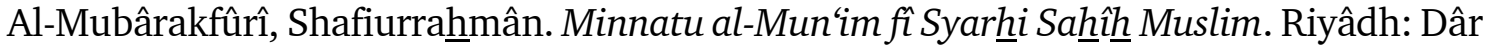
al-Salâm, 1999.

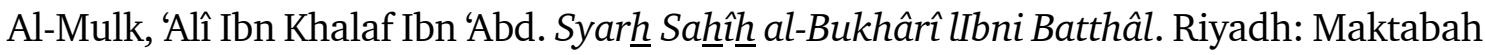
al-Rusy, t.t.

Al-Nawawî, Abû Zakariyâ Muhyiddîn bin Syaraf. al-Majmû‘ Syaraḩ al-Muhadzdzab. Beirut: Dâr al-Fikr, t.t.

Al-Nawawî, Muhyiddîn Ibn Syarf. Sahîh Muslim bisyarhí al-Nawawî. Kairo: al-Mathba'ah al-Mishriyah, t.t.

Al-Qalyûbî, Ahmad bin Salamah. ㅂâsyiyah Qalyûbî. Kairo: Musthafâ al-Bâbî al-Halabî, 2007.

Al-Qarâfî, Ahmad Ibn Idrîs Ibn 'Abdurrahmmân al-Shanhâjî. Nafâ' is al-Ushûl fî Syarh alMahshhûl. Riyâdh: Nazzâr Mushthafâ al-Bâz, 1995.

Al-Qardhâwî, Yûsuf. Kaifa Nata'âmal ma'a al-Sunnah al-Nabawiyyah, Cet. 2. Kairo: Dâr al-Syurûq, 2000.

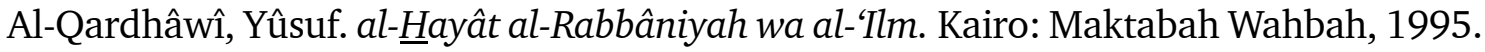

Al-Qardhâwî, Yûsuf. al-Islâm ㅂadhârah al-Ghad. Kairo: Mahtabah Wahbah, 1995.

Al-Qardhâwî, Yûsuf. Syarî’at al-Islâm Shâlihat li al-Tatbîq fí Kulli Makan wa Zamân. Kairo: Dâr al-Shahwah, 1993.

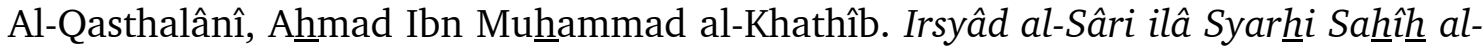
Bukhârî. t.t.p: al-Mathba'ah al-Kubrâ al-Amîriah, $1323 \mathrm{H}$.

Al-Qurthubî, Aḥmad Ibn 'Umar Ibn Ibrâhîm. al-Muflim limâ Asykala min Talkhîsh Kitâb Muslim. Beirut: Dâr Ibn Katsîr, 1996.

Al-Ramlî, Muḥammad bin Abî 'Abbâs. Nihâyah al-Muhtâj Ilâ Syarh al-Minhâj. Beirut: Dar al-Fikr, t.t.

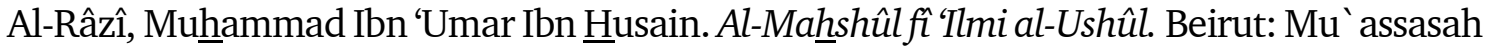
al-Risâlah, t.t.

Al-Sam'ânî, Manshûr Ibn Muhammad Ibn 'Abd al-Jabbâr. Qawâthi'u al-Adillah fí al-Ushûl. Beirut: Dâr al-Kutub al-'Ilmiah, 1997.

Al-Sanûsî, 'Abdullâh Munhammad Ibn Muhammad Ibn Yûsuf. Mukammil Ikmâl al-Akmâl. Beirut: Dâr al-Kutub al-'Ilmiah, t.t.

Al-Subkî, Mahmûd Muhammad Khatthâb. al-Manhal al-'Adzbu al-Maurûd. Beirut: Mua'ssasah al-Tarikh al-'Arabi, t.t.

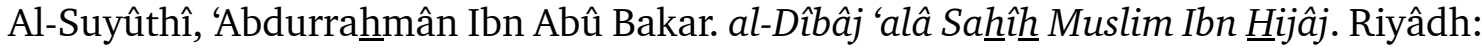
Dâr Ibn 'Affân, 1996.

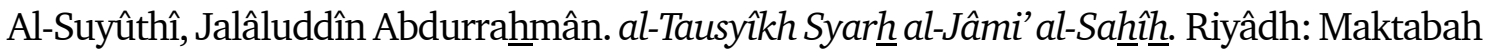
al-Rusy, 1998.

Al-Suyûthî, Jalâluddîn Ibn 'Abdurrahmân Ibn Abû Bakar. Miftâh al-Jannah fí al-I'tishâm bi al-Sunnah. Riyâdh: Maktabah al-Sầ̂, 1987. 
Al-Suyûthî, Jalâluddîn. Syarh al-Kaukab al-Sâthi'. Kairo: Maktabah al-Imân, 2002.

Al-Syâfi'î, Muhammad Ibn Idrîs. al-Risâlah. Beirut: Dâr al-Kutub al-'Ilmiah, t.t.

Al-Syâmî, Shâlih Ahmad. Zawấid al-Sunan. Riyâdh: Dâr al-Nafâ'is, 1998.

Al-Syarbînî, Muhammad bin al-Khathîb. Mughnî al-Muhtâjj ilâ Ma'rifati Alfâdl al-Minhâj. Beirut: Dâr al-Ma'rifah, 1998.

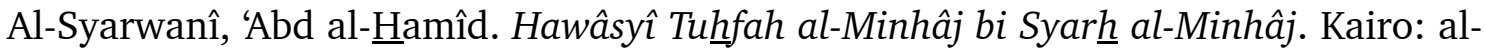
Maktabah al-Tijâriyah al-Kubra, 2007.

Al-Syâthibî, Abû Ishâq Ibrâhîm al-Lakhmî. al-Muwâfaqat fî Ushûl al-Ahhkâm. Beirut: Dâr al-Fikr, t.t.

Al-Syaukânî, Muhammad Ibn 'Alî Ibn Muhammad. Nail al-Authâr Syarh Muntaqâ alAkhbâr. Mesir: Mathba'ah Mushthafâ al-Bâbî al-Halabî, t.t.

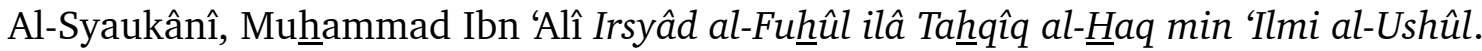
Riyâdh: Dâr al-Fadhîlah, 2000.

Al-Syinqithî, Muhammad al-Amîn Ibn Muhammad al-Mukhtâr. Mudzakkirah fí Ushûl alFiqh. Madinah: Maktabah al-'Ulûm wa al-Hikam, t.t.

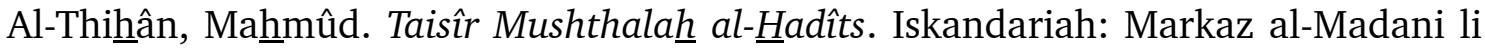
Dirâsât, $1415 \mathrm{H}$.

Al-Thûfî, Sulaimân Ibn 'Abd al-Qawî Ibn 'Abd al-Karîm Ibn Sa'îd. Syarhnu Mukhtashar alRaudhah. Beirut: Mu'assasah al-Risalah, 1987.

Al-Wasytânî, 'Abdullâh Muhammad Ibn Khalfah. Ikmâl Akmâl al-Ma'lam. Beirut: Dâr alKutub al-'Ilmiah, t.t.

Al-Yahshabî, 'Iyâdh Ibn Mûsâ Ibn 'Iyâdh. Ikmâl al-Mu'lim bi Fawâ 'idi Muslim. t.t.p.: Dâr al-Wafâ', 1998.

Al-Zuhailî, Wahbâh. al-Wajîz fî Ushûl al-Fiqh. Beirut: Dâr al-Fikr, 1999.

Al-Zuhailî, Wahbah. Ushûl al-Fiqh al-Islâmî, cet. 17. Beirut: Dâr al-Fikr, 2009.

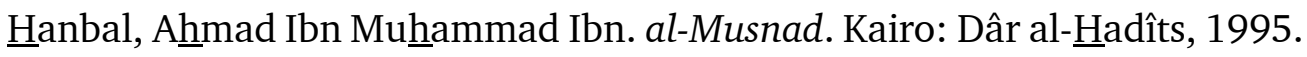

Katsîr, Ismâ̂îl Ibn 'Umar Ibn. Tafsîr al-Qur'an al-Azhîm. t.t.p.: Dâr Thayyibah, t.t.

Khallâf, 'Abd al-Wahhâb.'Ilmu Ushûl al-Fiqh, cet.12. t.t.p.: Dâr al-'Ilmi, 1978.

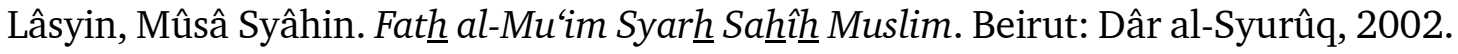

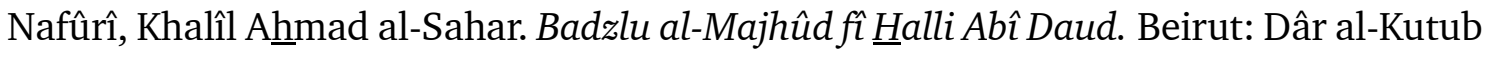
al-'Ilmiah, t.t.

Nujaim, Zainuddîn Ibn Ibrâhîm Ibn. Misykât al-Anwâr fĩ Ushûl al-Manâr. Kairo: Mushthafâ al-Bâbî al-Halabî, 1936.

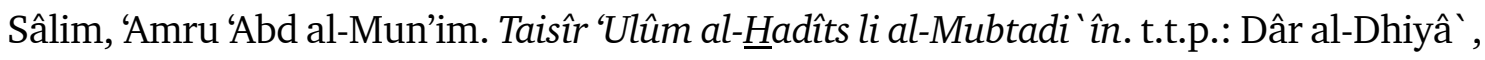
2000.

Shâlih, Sulaimân Ibn. Al-Qardhâwîfî al-Mîzan. Riyâdh: Dâr al-Jawâb, t.t. 
MIQOT Vol. XXXIX No. 2 Juli-Desember 2015

Zaid, Nashr ㅂâmid Abû. Mafhûm al-Nash: Dirâsah fì 'Ulûm al-Qur'an. t.t.p.: al-Hai'ah alMishriyah al-'Âmmah li al-Kitâb, 1993.

Zaidan, Muhammad al-Amîn Ibn Aḥmad. Marâqî al-Su'ûd ilâ Marâqî al-Suyûd. Kairo: Maktabah Ibn Taimiyah, 1993. 